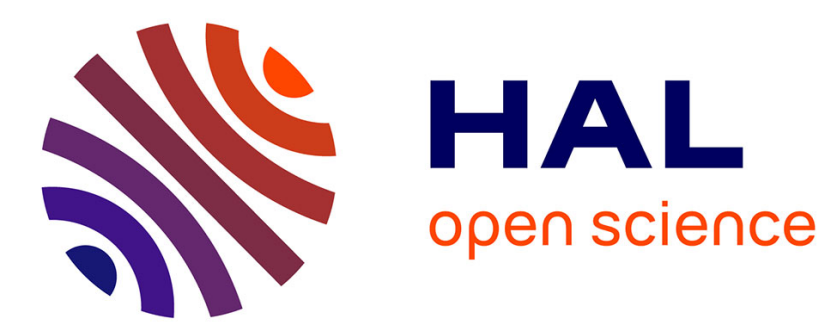

\title{
Phonemic and tonal analysis of the Pianding dialect of Naxi (Dadong County, Lijiang Municipality)
}

\author{
Alexis Michaud, Likun He
}

\section{To cite this version:}

Alexis Michaud, Likun He. Phonemic and tonal analysis of the Pianding dialect of Naxi (Dadong County, Lijiang Municipality). Cahiers de linguistique - Asie Orientale, 2015, 44 (1), pp.1-35. 10.1163/19606028-00441p01 . halshs-01098742v2

\section{HAL Id: halshs-01098742 \\ https://shs.hal.science/halshs-01098742v2}

Submitted on 12 Apr 2015

HAL is a multi-disciplinary open access archive for the deposit and dissemination of scientific research documents, whether they are published or not. The documents may come from teaching and research institutions in France or abroad, or from public or private research centers.
L'archive ouverte pluridisciplinaire HAL, est destinée au dépôt et à la diffusion de documents scientifiques de niveau recherche, publiés ou non, émanant des établissements d'enseignement et de recherche français ou étrangers, des laboratoires publics ou privés.

\section{(ㅇ)(1) $\$$}

Distributed under a Creative Commons Attribution - NonCommercial - NoDerivatives $\mid 4.0$ 
Phonemic and tonal analysis of the Pianding dialect of Naxi (Dadong County, Lijiang Municipality)

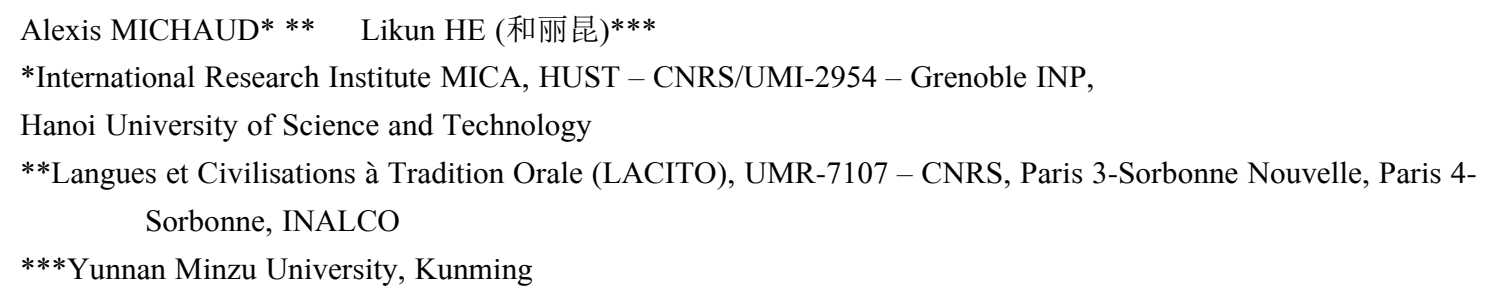

\begin{abstract}
This article sets out a phonemic and tonal analysis of the second author's native language: the (heretofore undescribed) Naxi dialect spoken in the village of Pianding (Dadong County, Lijiang Municipality, Yunnan). A distributional inventory brings out two pairs of phonemes that are of special interest to Naxi dialectology: (i) two apicalized vowels, $/ \mathcal{q}$ and $/ 1 /$, and (ii) two rhotic vowels, $/ \mathfrak{r} /$ and $/ \mathrm{ur} /$, instead of only one apicalized vowel and one rhotic vowel in Lijiang Old Town (Dayanzhen), the best-described dialect to date. These observations confirm and complement reports from other dialects; information on the lexical distribution of these conservative oppositions enriches the empirical basis for comparative-historical studies within the Naish subgroup of Sino-Tibetan. In the course of the discussion, observations about the Pianding dialect are placed in cross-dialect perspective; this article can thus serve as an introduction to key aspects of Naxi phonemics.
\end{abstract}

\title{
1. Introduction
}

\subsection{Research agenda}

This groundwork article sets out a phonemic and tonal analysis of the second author's native language: the Naxi dialect spoken in the village of Pianding (Dadong County, Lijiang Municipality, Yunnan). A phonemic and tonal analysis based on a distributional inventory constitutes a necessary basis for all aspects of linguistic documentation and research, from the accurate transcription of recorded materials to fine-grained synchronic and diachronic investigations. The present analysis thereby represents a contribution to the long-term endeavour to document and study the dialectal diversity of the Naish subgroup of Sino-Tibetan, which includes Naxi, Na (a.k.a. Mosuo, Narua; see Lidz 2010) and Laze (Huáng Bùfán 2009). The existence of increasingly refined analyses for other language varieties within the Naish subgroup helps focus the discussion on phonemic oppositions of special interest for diachronic studies. ${ }^{1}$ In the course of the discussion, observations about Pianding Naxi are placed in cross-dialect perspective; this article can thus serve as an introduction to key aspects of Naxi phonemics.

\footnotetext{
${ }^{1}$ Reviews of the state of the art in research on Naxi and the Naish subgroup of Sino-Tibetan are proposed by Li (2014) and Michaud, He Limin \& Zhong Yaoping (forthcoming). 


\subsection{Theoretical backdrop}

The theoretical backdrop to the present research is classical functional phonology (Martinet 1956:15, 34-47). Specifically, this research follows the approach advocated by Martinet under the name dynamic synchrony (Martinet 1990): synchrony and diachrony are kept clearly distinct, but synchronic observations are placed in evolutionary perspective. The ultimate research aim consists in documenting the diachronic evolution from Proto-Naish to each of the present-day dialects, with a degree of detail that approaches the standards of full-fledged sociolinguistic studies. Labov's Principles of Linguistic Change (Labov 1994, 2001, 2010) are a source of inspiration in this longterm endeavour. From a cross-linguistic point of view, case studies that shed light on the conditioning of individual sound changes can ideally contribute to the formulation of panchronic laws: language-independent laws of sound change, obtained by induction from a typological survey of precise diachronic events whose analysis brings out their common conditions of appearance (Haudricourt 1940; Mazaudon \& Michailovsky 2007). For instance, the observation of nasalized syllables in a Naxi dialect provided the starting-point for an investigation that progressed from comparison within Naish to comparison across Sino-Tibetan and finally to a panchronic study of transfer of nasality between consonantal onset and vowel (Michaud, Jacques \& Rankin 2012). Hope of making such discoveries is a major motivation in sifting through dialect data.

\subsection{Target language and reference speaker}

The language variety under study is spoken in the hamlet of Pianding (片丁), about 70 kilometers to the north-north-east of the city of Lijiang (丽江): see map. [INSERT MAP ON A FULL PAGE, ON THE PAGE THAT FOLLOWS THE ABOVE PASSAGE: "The language variety under study is spoken in the hamlet of Pianding...”.] It is located at a latitude of $27.176 \mathrm{~N}$, and a longitude of 100.389 E. Its current administrative coordinates are: Pianding hamlet, Baishui village, Dadong township, Lijiang Municipality, Yunnan, China (云南省丽江市古城区大东乡白水村委会片丁村). Family genealogies suggest that the hamlet was founded around the year 1860, initially by Naxi families. The current population is about 40 families: thirteen Naxi families coming from two distinct places (presumed to be Baoshan 宝山 and Sanba 三坝), and maintaining distinct ritual habits to this day; and Han Chinese families, who appear to have settled gradually, family after family, since about the year 1900. All Naxi families in the hamlet carry the name He 和, whereas Han Chinese families carry various names: mostly Ma (马) - probably the earliest settlers after the Naxi but also Wang (王), Zhu (朱), Luo (罗), Yao (姚) and Zhang (张). The Yao and Zhu families, who are later arrivals, maintain a tradition of speaking Chinese, whereas transmission of the Chinese language was lost for the earlier Han Chinese settlers, whose mother tongue is now Naxi. The endonym of the Naxi language is /na $」$ çit/.

One of the authors of this study (He Likun) is a native speaker of Pianding Naxi. The status of native speaker is often considered to be, in and of itself, indicative of the very best linguistic competence, requiring no further elaboration. In our view, however, it is crucial to provide further indications page 2 


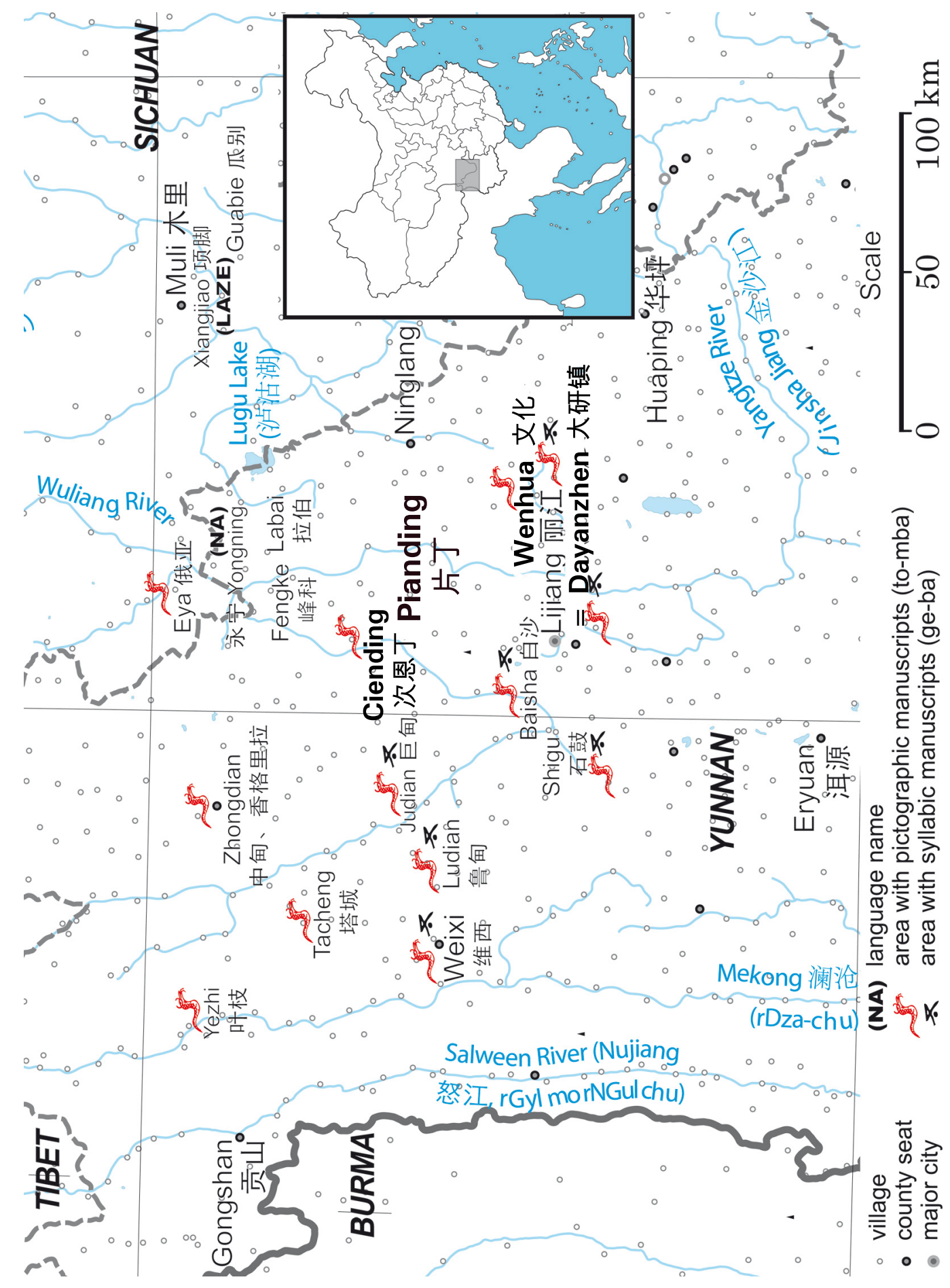


about the speakers. Speech data acquisition is an underestimated challenge (Niebuhr \& Michaud 2015); bilingual or multilingual subjects are potentially brilliant collaborators in speech data collection, but one should be aware of potential bias. Speakers with high aural sensitivity, good short-term and working memory, high attentional ability and extensive vocabulary knowledge attune fastest to different accents (Janse \& Adank 2012). This is likely to affect their performance as language consultants when living in a language environment other than that of their mother tongue. An individual's experience of different languages, dialects and sociolects exerts a deep influence on the way s/he speaks. Among other spectacular experimental findings, it has been shown that one minute of exposure is enough for the ear to attune to a foreign accent (Clarke \& Garrett 2004). Such phonetic-accommodation effects are reflected in amplified and entrenched forms in the speech of bilingual or multilingual speakers, who are generally "unable to avoid long term interference" (Watson 2002:245). To take an example within the Himalayan linguistic area, a review of a study of the Lhasa Tibetan tone system points out uncertainties due to the main consultant's life story, and emphasizes that fine points in phonology "would be better established with the typical monolingual (mono-dialectal) native informant" (Mazaudon 1985:94). In view of the importance of this issue, we provide detailed information on the reference consultant.

He Likun was born in 1988 to monolingual parents. Until the age of 12, he lived at the hamlet, where he attended primary school. He then spent three years studying at the Nationalities Middle School (民族中学) in Nankou (南口), a place that has since been promoted to the status of Yulong County seat within Lijiang Municipality (丽江市玉龙县县城). After this, he returned to his home hamlet for one year, then spent three years in the city of Lijiang, completing middle school and then attending high school (from 16 to 19 years old). The first variety of Chinese that he learnt, at middle and high school (after receiving a smattering of it at his home hamlet's primary school), was a variety of Standard Mandarin spoken by Naxi people, and heavily influenced by Naxi pronunciation. It is locally known as "Naxi Common Speech": “Na Pu” (纳普) (full form: 纳西普通话 or 纳西族 汉语普通话), and is perceived as a substandard variety of Standard Mandarin, this being referred to by contrast as “Biao Pu” 标普, or “Standard Common Speech" (标准普通话). He Likun also has a passive knowledge of Southwestern Mandarin (the dominant Chinese dialect of Yunnan and Sichuan), of which he has never been a fluent speaker. From the ages of 20 to 24, he was an undergraduate at Northern University for Nationalities (北方民族大学) in Ningxia (宁夏), where he learnt Standard Mandarin, largely through self-study, losing fluency in "Na Pu" (纳普) during the process. He acquired some passive knowledge of other Naxi dialects, but never felt social pressure to adopt another pronunciation than that of his home hamlet. He remains a fluent speaker, using Pianding Naxi in oral communication with his relatives. Since 2012, he has been a research student at Yunnan University for Nationalities (云南民族大学). The data reported here were verified with Likun's father; the only differences that appeared concern the lexicon: Likun had (i) more limited lexical competence, lacking knowledge of some Naxi vocabulary still mastered by his father and 
(ii) a less sharp perception of the boundary between recent loanwords (which have a huge impact on the inventory of syllables, as evidenced by Table 4) and older lexical stock.

\section{The consonant system}

Like the dialects of Ciending and Eya (see map), the Pianding dialect is more conservative than the speech of Lijiang Old Town (a.k.a. Dayanzhen dialect), which has the official status of "Standard Naxi". But while Pianding Naxi is relatively conservative in terms of its number of phonemes, its syllabic structure is nonetheless highly eroded. There are no codas or consonant clusters in any dialect of Naxi, making it, in this respect, typological opposite from not-so-distantly related Rgyalrong (Jacques 2004:12-82). Syllabic structure only consists of $(C)(G) V+$ Tone, where $C$ is a consonant, $\mathrm{G}$ a glide, and $\mathrm{V}$ a vowel or syllabic consonant. The present article successively discusses consonants, vowels and tones. An inventory of syllables in simple initial * rhyme table form is proposed in Table 4 (Section 5).

Consonant phonemes are shown in Table 1.

Table 1. Consonant phonemes of Pianding Naxi.

\begin{tabular}{|c|c|c|c|c|c|c|c|}
\hline & bilabial & dental & retroflex & alveolo-palatal & palatal & velar & glottal \\
\hline stop & $\mathrm{p}^{\mathrm{h}} \mathrm{p} \quad \mathrm{b} \quad \mathrm{mb}$ & $\mathrm{t}^{\mathrm{h}} \mathrm{t} d \mathrm{nd}$ & & $t_{6}^{\mathrm{h}} \mathrm{t}_{6} \mathrm{~d} / \mathrm{nd} / 6$ & $c^{h} c_{f n f}$ & $\mathrm{k}^{\mathrm{h}} \mathrm{kg} \mathrm{gg}$ & \\
\hline affricate & & $\mathrm{ts}^{\mathrm{h}}$ ts dz ndz & $\mathrm{ts}^{\mathrm{h}} \mathrm{ts} \mathrm{dz}, \mathrm{ndz}$ & & & & \\
\hline fricative & fv & s z & S Z & & ç & & $\mathrm{h}$ \\
\hline nasal & $\mathrm{m}$ & $\mathrm{n}$ & & & $\mathrm{n}$ & y & \\
\hline $\begin{array}{l}\text { lateral } \\
\text { approximant }\end{array}$ & & 1 & & & & & \\
\hline
\end{tabular}

The presentation below lays emphasis on points of special interest.

\subsection{Velars, palatals and alveolopalatals}

Pianding Naxi contrasts palatal and alveolopalatal initials, e.g. /dzit/ 'human being; living thing' vs. /yit/ 'shirt'. In view of the current distribution of velar and palatal initials, it appears likely that a change took place from $* k$ to $[\mathrm{c}]$ in front of palatalizing sounds: high, front vowels or rhymes beginning in a $/ \mathrm{j} /$ glide. The structural gap left open by this evolution is in the process of being filled by onomatopoeic expressions, such as /kittit-kotto-t/ and $/ \mathrm{k}^{\mathrm{h}} \mathrm{i}-\mathrm{t} \mathrm{si}-\mathrm{k}^{\mathrm{h}} \mathrm{o}-\mathrm{so}-\mathrm{t}$ 'sound of small animals scurrying around (outside one's field of vision)', so that a synchronic description must acknowledge phonemic velars, palatals, and alveolopalatals.

This raises the issue of the analysis of syllables such as [c-l] 'leprosy' or [cr-t] 'neck': they are likely to originate in ${ }^{*} \mathrm{kj} \gamma-1$ and ${ }^{*} \mathrm{kj} r-1$, respectively, with subsequent palatalization of the initial; if one recognizes phonemic /c/, they could be interpreted as $/ \mathrm{cr}^{-1 /}$ and $/ \mathrm{cr}-1 /$. The same analysis could 
then be extended to other rhymes with a palatal onglide, such as $/ \mathrm{j} /$, interpreting $\left[\mathrm{c}^{\mathrm{h}} j æ\right]$ as $/ \mathrm{c}^{\mathrm{h}} \mathfrak{x} /$, for instance.

The inventory in Table 4 (Section 5) is especially useful in handling such issues, as it brings out combinatorial properties of initials and rhymes (the latter consisting of the glide, if any, plus the nucleus). Table 4 reveals that rhymes such as $/ \mathrm{jæ} /$ and $/ \mathrm{j} \gamma /$ are attested in a relatively large number of environments; this lends support to the hypothesis that $\left[\mathrm{c}^{\mathrm{h}} \mathfrak{x}\right]$ is the product of the palatalization of a velar initial by a $/ \mathrm{jæ} /$ rhyme. Phonemic interpretation without a palatal on-glide after palatal initials (e.g. interpreting $\left[\mathrm{c}^{\mathrm{h}} \mathfrak{}\right.$ ] as $/ \mathrm{c}^{\mathrm{h}} \mathfrak{x} /$ ) in effect recognizes the metamorphosis of this syllable, with a transfer of the palatal articulation from the rhyme to the initial. This amounts to postulating a diachronic reinterpretation of $/ \mathrm{jæ} /$ as $/ \mathfrak{x} /$ in this context (i.e. after an initial which was formerly velar, but has now become palatal).

The second author's native-speaker intuition on this issue is not clear-cut. The question is whether the rhymes in [łæJ] 'very' and the first syllable of /jæ-kæ $\rfloor \mathrm{z} /$ ' 'husband' are the same or not, i.e. whether phonemic interpretation of the former should be $/ \mathfrak{f}+j æ J /$ or $/ \mathfrak{f}+\mathfrak{J} /$. These rhymes are transcribed here without a palatal on-glide, indicating that the transfer of palatality to the onset is deemed to be complete, hence /c $\gamma /$ / for 'leprosy' and /yæJ/ for 'very'. (A similar solution was adopted for Yongning Na: see Michaud 2008.) This issue is also relevant for other Naxi dialects such as Wenhua, where the structural situation (in terms of the syllable inventory) is the same.

The sound $[\mathrm{n}]$ likewise results from the palatalization of earlier *n and $* \mathrm{y}$ before high, front vowels (or rhymes beginning with the palatal glide $/ \mathrm{j} /$ ). No sound has yet filled the empty phonetic slots [ni], [njæ], [njr], [ny] created by the palatalization process. In view of the recognition of palatal stops as a distinct set of initial consonants, it appears reasonable to extend the same treatment to nasals, granting phonemic status to $/ \mathrm{n} /$. This amounts to the hypothesis - testable by psychophonetic methods - that this sound is not currently perceived as an allophone of $/ \mathrm{y} /$.

\subsection{Allophones of the glottal initial $/ \mathrm{h} /$}

Mazaudon \& Michailovsky (1979) analyze Old Town Naxi glottal, velar and palatal unvoiced fricatives as allophones of a glottal phoneme $/ \mathrm{h} /$. This analysis is adopted here for the Pianding dialect. From a phonetic point of view, the realization of $/ \mathrm{h} /$ is strongly influenced by the articulation of the following vowel: in the Naxi dialects that we are familiar with, a narrow phonetic notation

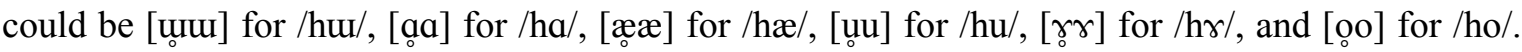
Allophonic variation does not appear to reach as far back as the uvular region, pace He and Jiang (1985:7), who posit (for the Old Town dialect) a phonemic velar fricative / $\mathrm{x} /$ that has a uvular allophone $[\chi]$ when associated with a /y/, /e/, /æ/, /a/, /o/ or /u/.

In the present state of Pianding Naxi, the analysis as $/ \mathrm{h} /$ is extended to the initial of loanwords such as /hwæ-t/ (from huāng 慌 'flustered, confused'), but as the pronunciation of Chinese borrowings 
becomes closer to the Southwestern Mandarin pronunciation, which seems to have more friction (e.g. [xwæy] for huāng 慌 'flustered, confused'), it may eventually result in the introduction of a bona fide $[\mathrm{x}]$ sound into the system, which could conceivably gain phonemic status, contrasting with $/ \mathrm{h} /$. Chinese loanwords have a huge impact on the inventory of syllables, as set out in detail in Table 4.

\subsection{Retroflex allophones of dental consonants}

Dental stop consonants $/ \mathrm{t}^{\mathrm{h}} /, / \mathrm{t} /, / \mathrm{d} /$ and $/ \mathrm{nd} /$, nasal $/ \mathrm{n} /$, and approximant $/ 1 /$ have retroflex allophones $\left[\mathrm{t}^{\mathrm{h}}\right.$ ], [t], [d], [nd], [l] and [n] in front of the back vowels $/ \mathrm{ur} /, / \mathrm{ur} /, / \mathfrak{\gamma} /, / \mathrm{u} /$, as well as before $/ \mathrm{w} æ /, / j \mathrm{j} /$ and $/ \mathrm{j} \gamma /$. Thus, for instance, [ $\left.\mathrm{t}^{\mathrm{h}} \mathrm{wæ}\right]$, [twæ] and [ndwæ] are analyzed as $/ \mathrm{t}^{\mathrm{h}} \mathrm{w} /, / \mathrm{tw} /$ and $/ \mathrm{ndwæ} /$. The combinatorial properties of the retroflex approximant [l] are discussed further in section 3.3.

\subsection{Onset-less syllables}

Onset-less syllables receive an empty-onset filler. Front close vowels have a [i] onset: the syllable /i/

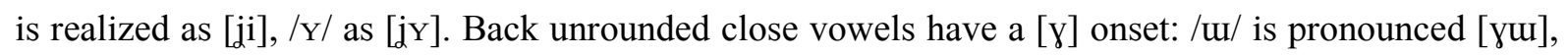
and $/ \gamma /$ as $[\gamma \gamma]$. For the back rounded close vowel $/ u /$, the empty-onset filler sounds like $[w]: / u /$ is realized as [wu]. For /o/, the empty-onset filler is noticeably weaker (a possible phonetic notation would be $\left[{ }^{\mathrm{h}} \mathrm{o}\right]$ ); this makes good sense in structural terms: realization as [wo], with a clear [w] onset, could threaten confusion with $/ \mathrm{w} r /$ or $/ \mathrm{wu} /$.

Onset-less syllables constitute a handy transition to the topic of vowels.

\section{The vowel system}

Leaving aside recent Chinese borrowings, the following vowels are found in Pianding Naxi: /i/, /Y/,

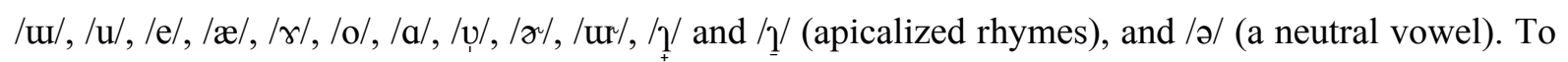
these must be added rhymes comprising a semi-vowel: /j $\gamma /$, /jæ/, /ja/; /w $\gamma /$, /wa/, and /wæ/. Readers are referred to Appendix B for examples. All of these rhymes have straightforward counterparts in Old Town, Wenhua and Ciending Naxi, except that (i) Old Town Naxi only has one rhotic rhyme (written $/ \mathfrak{\gamma} /$ ): Pianding $/ \mathfrak{\gamma} /$ and $/ \mathrm{ur} /$ both correspond to Old Town $/ \mathfrak{\gamma}$, as will be explained below, and (ii) Pianding $/ \mathfrak{q} /$ and $/ \mathfrak{q} /$ both correspond to the same rhyme in Old Town Naxi, where it is analyzed as an allophone of /u/.

In addition to these main rhymes, the Pianding phonological system contains some outliers. The rhyme /we/ is mostly found in Chinese borrowings, such as /kwe / 'expensive, precious' (from gui 贵), but also in two items of native vocabulary: 'willow tree', /zwe רhæ」/ (compare Ciending /zul1/ and Wenhua $/ \mathrm{z}^{\mathrm{w}} \mathrm{\gamma}-\mathrm{f}$ ), and /hwe $\mathrm{J} /$ 'to wrestle'. The semivowel $[\mathrm{\Psi}]$ is analyzed as an allophone of /w/, after initials with dental to palatal points of articulation. This analysis requires positing a sequence of glides /jw/ for the Chinese borrowing [jue1] 'moon' (from yuè 月): it can be phonemicized as /jwe1/ page 6 
(distinct from the /w/-initial syllable/we/, as in /we」/ 'to surround' (from wéi 围). The [чæ] rhyme has been introduced via recent borrowings from Southwestern Mandarin, e.g. [cчæ-] 'to contribute' (from juān 捐), [c ${ }^{\mathrm{h}} \mathrm{Yæ-1}$ 'pen, sty' (from quān 圈) and [juæ-1] 'injustice' (from yuān 冤). It is phonemicized as /wæ/, hence the transcription of the three preceding examples as /cwæ-t/ 'to contribute', /c ${ }^{\mathrm{h}} \mathrm{w}-1 /$ 'pen, sty' and /jwæ/ 'injustice' (with the same initial /j/ as in /jwe1/ 'moon').

As a preliminary to the discussion of the phonemic and phonotactic properties of the rhymes, Figures 1 and 2 show phonetic data on the Pianding Naxi vowel space. These two figures are based on one token of each vowel, spoken in isolation by He Likun in a recording booth, in syllables with an empty phonological onset. ${ }^{2}$ The accuracy of formant frequency estimation was verified by visual inspection on PRAAT's spectrographic display during the annotation of these vowels; formant frequencies were then automatically retrieved at $1 / 3,1 / 2$ and $2 / 3$ of vowel duration using Cédric Gendrot's PRAAT script ANALYSE1 (Gendrot, n.d.). The values represented on the figures show the average of measurements at these three time points. Spectrographic observation suggests that formant movement in the course of the vowel is so limited that one average value for each vowel provides a good approximation of vowel quality. Needless to say, a full-fledged acoustic study of Pianding Naxi vowels would require a much more sophisticated procedure for data collection and processing, in order to arrive at a reasonably speaker-independent view of the system. Figures 1 and 2 nonetheless offer a glimpse of the system's acoustic outlook. Figure 2 suggests that F3 plays an important role in the Pianding Naxi vowel space: in particular, the two rhotic vowels, $/ \gamma /$ and $/ \mathrm{ur} /$, which are neighbours to the apicalized vowel $/ \mathrm{I} /$ in the F1-F2 plot (Figure 1), are far apart from it on the F3 axis (Figure 2). The vowel /a/ has a slightly lighter tinge than the others to reflect its marginal status.

\footnotetext{
${ }^{2}$ We plan to make this and other recordings available through the Pangloss Collection, about which see Michailovsky et al. (2014). Naxi materials in the Collection are available from:

http://acito.vjf.cnrs.fr/pangloss/languages/Naxi_en.htm 


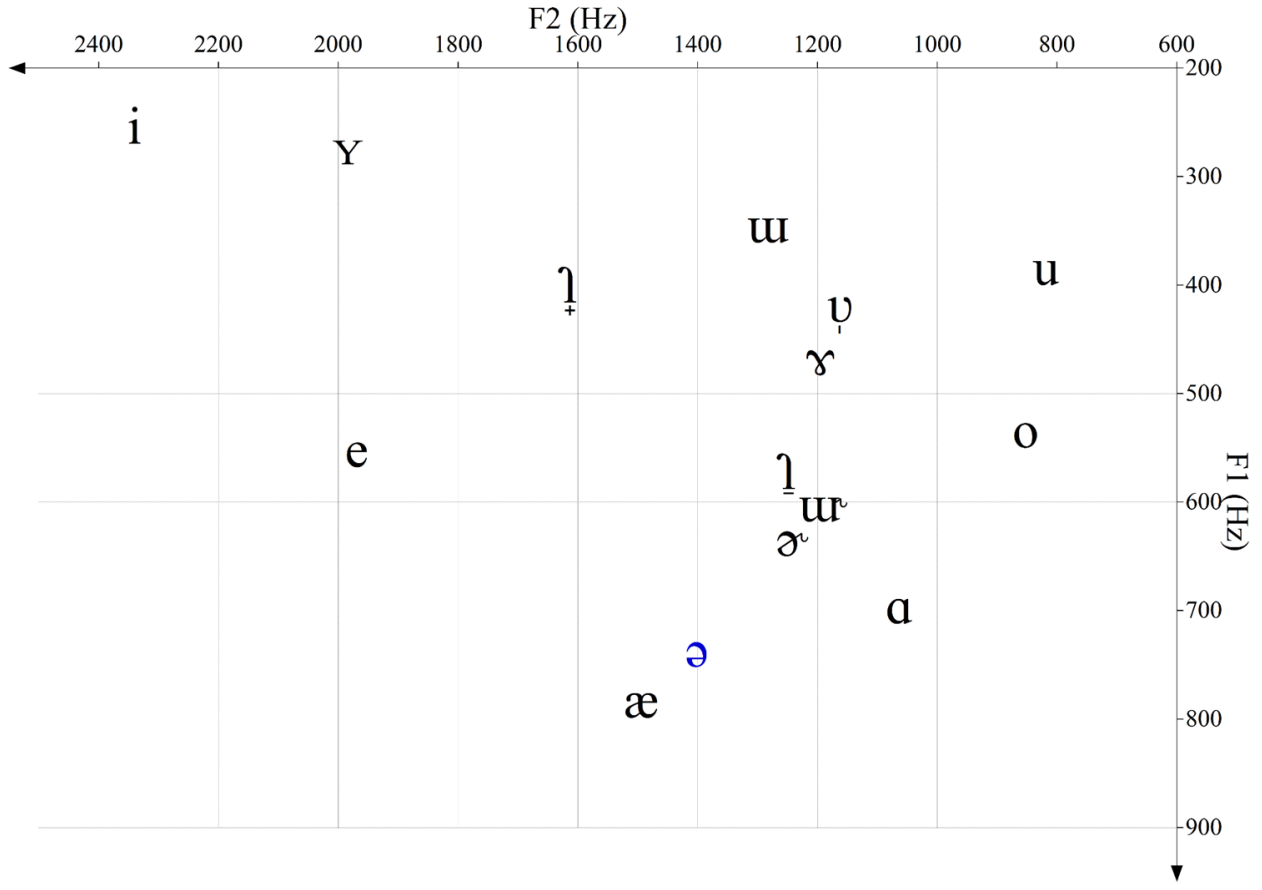

Figure 1. A F2-F1 representation of Pianding Naxi vowels, based on 1 token of each vowel by He Likun.

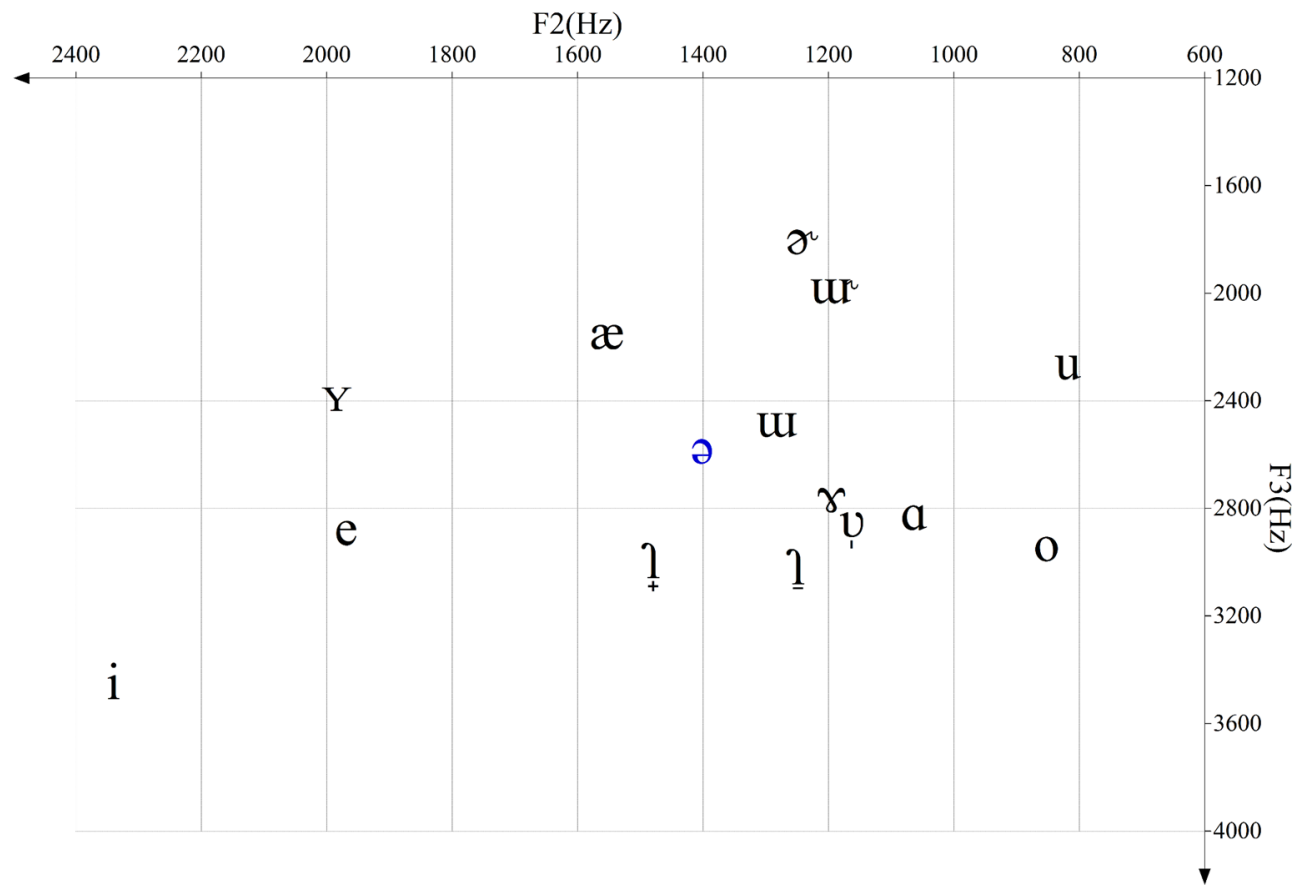

Figure 2. A F2-F3 representation of Pianding Naxi vowels, based on 1 token of each vowel by He Likun. 


\subsection{Close front vowels $/ \mathrm{i} /$ and $/ \mathrm{Y} /$}

Pianding has a rounded high front vowel, as do the Old Town and Wenhua dialects. This vowel is commonly transcribed as /y/ in Naxi (e.g. Fāng Guóyú 方国瑜 \& Hé Zhìwǔ 1995; Pinson 2012). In the case of Pianding Naxi, however, this vowel is articulated somewhere between close [y] and close-mid [ø]. This echoes an observation made by He Jiren and Jiang Zhuyi (Hé \& Jiāng 1985:10) that "when $/ y /$ combines with a bilabial or laminal-alveolar initial, or with the velar initial $/ x /$, its phonetic realization is $ø "{ }^{3}$ Accordingly, this vowel is here transcribed as $/ \mathrm{Y} /$. Note that the same choice was made by the linguist Chang K'un (張琨) in his notation of the speech of Mr. He Cai (和 才), a Naxi speaker born in Ludian (鲁甸) L,(Li Lin-ts'an, Chang K’un \& Ho Ts'ai 1953:xxiv).

The phonetic realization of $/ \mathrm{Y} /$ in Pianding is consistent with its position within the phonological system. Whereas, among the non-rounded vowels, close /i/ and mid /e/ contrast with each other, and hence must be phonologically specified as close vs. mid, there is only one rounded front vowel. This vowel can therefore range freely inside the close and close-mid phonetic vowel space. A phonological consequence is that $/ \mathrm{Y} /$ should not necessarily be viewed as the rounded counterpart of /i/ (or of /e/); rather, the close vs. mid opposition can here be said to be neutralized.

The non-rounded close front vowel in Pianding Naxi is not noticeably different from its counterpart in Old Town or Wenhua, and is transcribed simply as /i/.

\subsection{Mid front vowel /e/}

The non-rounded mid vowel in Pianding Naxi could be transcribed as either /e/ or / $/ \varepsilon$, as there is no opposition between a close-mid and open-mid vowel. There is currently no clear standard to refer to when facing a choice between two vowel symbols such as these. In the past, Principles of the International Phonetic Association recommended the use of roman letters: "When a vowel is situated in an area designated by a non-roman letter, it is recommended that the nearest appropriate roman letter be substituted for it in ordinary broad transcriptions if that letter is not needed for any other purpose" (International Phonetic Association 1949:7). ${ }^{4}$ However, this was based on considerations of

\footnotetext{
${ }^{3}$ Original text: “y 与双唇音、舌尖中音声母和舌根音声母 $\mathrm{x}$ 相拼时, 其实际音值为 $\varnothing 。 ”$ It is hard to ascertain which particular dialect the authors had in mind when stating this observation, since the book combines data from several dialects, including Dayanzhen (大研镇), i.e. Lijiang Old Town, chosen as standard; Yangxi (漾西), which is He Jiren's native dialect; and Qinglong (青龙), present-day Changshui (长水), the hometown of He Zhiwu 和志武, who was Jiang Zhuyi's main tutor in Naxi studies (He Jiren and Jiang Zhuyi, p.c. 2001).

${ }^{4}$ John Wells still uses this argument in favour of the symbol/e/ for British English (Wells 2001); this is rather confusing for foreign learners of British English, however. Hughes, Trudgill and Watt (2013:49) provide the following clarification: " $/ \varepsilon /$, as in pet. An $[\varepsilon]$ which is close to Cardinal Vowel 2, [e], may sometimes be heard amongst older upper-class speakers and those who would use them as models. By the late 1980s, Gimson (1988) had labelled this realisation as 'over-refined' while one which forms a glide towards [ə] is perceived as affected; such perceptions continue today". It is not clear to what extent the present-day $[\varepsilon]$ realizations may page 9
} 
typographical convenience which are not so relevant anymore since the advent of Unicode, and phonetic accuracy appears to be a more desirable goal. The issue of the choice of phonetic symbols for this particular vowel is illustrated in previous descriptions of Naxi phonemes. He and Jiang (1985:9) have observed, for dialects of the Lijiang plain, that "when /e/ combines with a bilabial or laminal-alveolar initial, its phonetic realization is $[\varepsilon] " .{ }^{5}$ Elsewhere, the symbol $/ \varepsilon /$ is used for this vowel, e.g. in a description of Ciending Naxi (Michaud \& Xú Jìróng 2012), where realizations are reported to be phonetically close to $[\varepsilon]$.

As one means of obtaining evidence in favour of either /e/ or / $/ \varepsilon$ for Pianding Naxi, an informal perception test was conducted, playing the vowel at issue (preceded by a labial stop) to a group of Vietnamese listeners. Vietnamese has four degrees of vowel aperture, contrasting /i/, /e/, / $/$ / and /a/ (Kirby 2011:384). The majority choice of the listeners was /e/ (ê in Vietnamese orthography) rather than $/ \varepsilon /$ (orthographic $e$ ). This does not constitute overwhelming evidence, however: in the absence of a front/back opposition for the open vowel (there is no /a/ contrasting with /a/), Vietnamese /i/, /e/ and $/ \varepsilon /$ can hardly be considered typical examples of the 'cardinal' front unrounded vowels of the IPA. The next step, which must be deferred until a later publication, would consist in acoustic analysis and modelling. The acoustic theory of speech production (Fant 1960) allows for a representation of acoustico-perceptual characteristics of speech sounds by reference to the resonantial properties of the vocal tract: the F-pattern. Unlike IPA notation, a characterization in terms of an Fpattern is sufficiently detailed to serve as input for speech synthesis, via articulatory modelling (Maeda 1996). Speech sounds can be characterized accurately in terms of a target F-pattern and of the articulatory configuration used to attain this pattern, hence the possibility of proposing a notation to describe the phonemes of individual languages by reference to certain fixed acoustical properties (Vaissière 2007; Vaissière 2011b).

\subsection{Back vowels $/ \mathrm{u} /, / \mathrm{u} /, / \mathrm{o} /$ and $/ \mathrm{\gamma} /$, and neutral vowel /a/}

Among the back vowels of Pianding Naxi, there are two unrounded vowels with clear phonemic status, and two rounded vowels, which can be considered either to be distinct phonemes or to be

constitute the result of a diachronic evolution (phonetic opening) of this vowel from [e] to $[\varepsilon]$ in the past century. In his review of Daniel Jones's 1909 The Pronunciation of English, however, Paul Passy already suggests that $\varepsilon$ would be a more appropriate choice than e for the vowel in pet. This suggests that realizations close to [e], as heard, for example, in Thomas Stearns Eliot's 1935 and 1946 audio recordings of The Waste Land, were already strongly marked from a sociolectal point of view at the time: the vowel [e] appears to be among the telltale characteristics of conservatism found in Eliot's pronunciation. Moreover, variation between phoneticians in the interpretation of Jones's Cardinal Vowels is illustrated by differences in the realization of these vowels by Daniel Jones compared with Peter Ladefoged, his student (Vaissière 2011a).

${ }^{5}$ Original quote: “e 与双唇音和舌尖中音声母相拼时, 其实际音值为 $\varepsilon$ 。” The same reservations as above apply here concerning the dialect at issue. In the dialects with which the authors are familiar, including Pianding, this phoneme is also realized as $[\varepsilon]$ after the glottal initial $/ \mathrm{h} /$.

page 10 
allophones, depending on the analysis chosen. After a lateral approximant, both [o] and $[\mathrm{u}]$ are found: [lo-1] 'work', [lu-t] 'to come (IMPERATIVE)'. Since both the initial and the rhyme differ in these two words, this creates a dilemma for phonemic interpretation: should one interpret the vowels as distinctive, and the coronal vs. retroflex articulation of the initial as conditioned by the vowel? Or conversely, should the vowel difference be analyzed as conditioned by the initial?

These two different analyses have been adopted for two different Naxi dialects, Old Town and Wenhua respectively, where the two morphemes [lo-1] 'work' and [lu-1] 'to come (IMPERATIVE)' are also found. In Old Town Naxi, considered in China as “Standard Naxi” (纳西语标准音), these morphemes are analyzed phonemically as /lot/ and / $\mathrm{lu}-/$ respectively by He and Jiang (Hé \& Jiāng 1985:7), who point out the complementary distribution of coronal and retroflex initials. An argument for this analysis in Old Town Naxi is that the vowels / $\mathrm{u} /$ and /o/ are also distinct after velars, witness $/ \mathrm{k}^{\mathrm{h}} \mathrm{u}-1 /$ 'door' vs. $/ \mathrm{k}^{\mathrm{h}} \mathrm{O}-1 /$ 'sound, noise'. The opposition of $/ \mathrm{u} / \mathrm{and} / \mathrm{o} /$ is diachronically secondary but is becoming well-settled inside the Old Town system, supporting the analysis of retroflexion on initial stops and laterals as being contextually conditioned. Hence the analysis of [lu], [lur $],\left[l^{\gamma}\right],[l u],[l v]$,

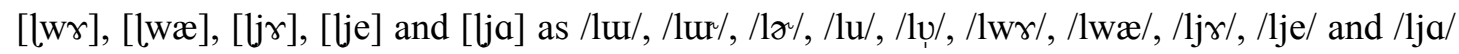
respectively.

For the Wenhua dialect, on the other hand, $/ 1 /$ and $/ / /$ are analyzed as distinct phonemes contrasting before /o/, e.g. /loJ/ 'inside' vs. /loJ/ 'yoke' (Michaud 2006a:41-42). In Wenhua, the noun [lo-1] 'work' is phonemicized as $/ \mathrm{lot} /$. As for the verb [lu-t] 'to come (IMPERATIVE)', in the absence of an opposition between $/ / /$ and $/ 1 /$ in front of $/ \mathrm{u} /$ (there is no [lu] syllable), its initial constitutes the neutralization of the l-vs.-1 opposition and could be written as L, to reflect its status as an archiphoneme ${ }^{6}$, hence $/ \mathrm{Lu}-/$. Notation as $/ \mathrm{lu}-/$ is more transparent phonetically, but less informative phonologically.

\footnotetext{
${ }^{6}$ Here is how Christopher Court explained the notions of neutralization and archiphoneme in his "expanded translation" of Haudricourt (1961): "One of the concepts of the Prague School which has won least acceptance in English-speaking countries is that of the neutralization of phonemic contrast. In order to illustrate this concept, let us take a case from English. In English we have two different phonemes $/ \mathrm{p} /$ and $/ \mathrm{b} /$. This is proved by dozens of minimal pairs, such as pit : bit, pat : bat and so on. $/ \mathrm{p} /$ is a fortis or strong sound, sometimes, but not always aspirated. /b/ is a lenis or weak sound, sometimes, but not always voiced, but always weaker in its articulation than $/ \mathrm{p} /$. However there is one environment, following the phoneme $/ \mathrm{s} /$ in the same syllable, in which the phonemes $/ \mathrm{p} /$ and $/ \mathrm{b} / \mathrm{do}$ not contrast: we do not have pairs of words spit : sbit, spat : sbat, and so on. The sound which we spell with a $\mathbf{p}$ in the words spit, spat etc., is phonetically something between a $/ \mathrm{p} /$ and a $/ \mathrm{b} /$, and the exact sound of $/ \mathrm{p} /$ or $/ \mathrm{b} /$ cannot occur in this environment. We say that the phonemic contrast between $/ \mathrm{p} /$ and $/ \mathrm{b} /$ is neutralized in this environment, and that the sound which is spelled $\mathrm{p}$ in spit, spat and so on, does not represent either the phoneme /p/ or /b/, but the "mother" phoneme, so to speak, of both $/ \mathrm{p} /$ and /b/. This "mother" phoneme is called the archiphoneme of the phonemes $/ \mathrm{p} /$ and $/ \mathrm{b} /$. Let us write it as "P". Then pit, bit and spit are phonemically /pit/, /bit/ and /sPit/. The actual sound which represents the archiphoneme /P/ -phonetically an unaspirated, voiceless stop- is called the phonetic "realization" or "representation" of the archiphoneme. Whenever we find an environment in which two closely related phonemes like $/ \mathrm{p} /$ and $/ \mathrm{b} /$ cannot both occur, we say that the one sound which can occur page 11
} 
In Pianding, it appears appropriate to recognize /o/ and $/ \mathrm{u} /$ as synchronically distinct phonemes, since /o/ and /u/ also contrast after /h/: /hu-/ 'to wait', /hot/ 'soup', with only very minor phonetic differences in the realization of the initial (slightly more friction for $/ \mathrm{hot} /$ ). The same phonemic analysis as in Old Town Naxi is therefore proposed: analyzing 'work' as /lot/, and 'to come (IMPERATIVE)' as /lut/.

For the unrounded back vowels, we adopt the notations $/ \mathrm{w} /$ and $/ \gamma /$. The vowel $/ \mathrm{u} /$ is identical to He and Jiang, Fang and He, and other authors' usage. Its apicalized allophones after coronal and retroflex fricatives and affricates are dealt with separately below. The vowel $/ \gamma /$ corresponds to $\mathrm{He}$ Jiren and Jiang Zhuyi's [ə]. In fact, their transcription (for Old Town, and also for the various other dialects that they mention) failed to distinguish between two vowels (see Michaud 2013a): (i) the back mid unrounded vowel $/ \gamma /$, realized as $[\gamma \gamma]$ in an onset-less syllable; and (ii) the neutral vowel $/ \mathrm{\partial} /$. It is the former that corresponds to Pianding $/ \gamma /$. The latter, on the other hand, always constitutes a syllable on its own, mostly as the initial syllable within disyllables. It appears in kinship terms referring to one's elders, and in various grammatical words (see word list). It harmonizes with the following syllable's vowel, and is realized with an initial glottal stop.

In Pianding Naxi, a phonetic study conducted by the second author (unpublished thesis) shows that the average phonetic realization of the neutral vowel /a/ is lower than the expected central target: it has a lower first formant than either the theoretical neutral vowel (for a male speaker: formants from 1 to 3 at 500, 1500 and $2500 \mathrm{~Hz}$, respectively) or the mean of all the full vowels in the system (Browman \& Goldstein 1992; Barry 1992). Realizations of the neutral vowel /ə/ are close to [æ]

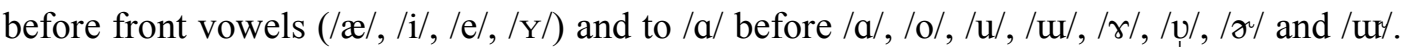

\subsection{Open vowels}

Pianding Naxi has two open vowels, corresponding straightforwardly to other Naxi dialects such as Old Town and Wenhua. Some authors transcribe these as /a/ vs. /æ/ (for instance Hé \& Jiāng 1985; Hé Kāixiáng et al. 1989), others as /a/ vs. /æ/ (Fāng Guóyú \& Hé Zhìwǔ 1995), still others as /a/ vs.

represents the archiphoneme of the two phonemes, and does not represent one or other of the two corresponding phonemes, even if phonetically it is exactly the same as one or other of the phonemes. Simply because the phonemes cannot both occur in that environment we say that the sound which does occur is, or represents, an archiphoneme.

In some cases the sound representing the archiphoneme will be something in between the two phonemes, as is the English /P/ in /sPit/, /sPæt/ and so on, but in other cases the sound representing the archiphoneme may be exactly the same as one or other of the phonemes. The important thing is that the sound $/ \mathrm{p} /$ does not represent the phoneme $/ \mathrm{p} /$ in a particular environment, unless the sound $/ \mathrm{b} / \mathrm{can}$ also occur and contrast phonemically with it in the same environment. Thus we could have a language very much like English, in which a sound, say, [p] represented the phoneme /p/ in one environment, because in that environment the sound $[\mathrm{b}]$ also occurred and contrasted phonemically with it, whilst in another environment the selfsame sound [p] represented the archiphoneme $(/ \mathrm{P} /)$ of $/ \mathrm{p} /$ and $/ \mathrm{b} /$, because in that second environment the partner-sound [b] could not occur and contrast with [p]." (Christopher Court, in Haudricourt 1972:77) 
/a/ (Fù Màojì 1981; Pinson 2012). The use of the symbol /a/ can cause some confusion for linguists who consult data from several sources, hence our decision to transcribe them as /æa/ and /a/, unambiguously bringing out their place within the front vs. back opposition.

\subsection{The fricative rhyme $/ v /$}

In Pianding Naxi, as in Ciending Naxi, the fricative rhyme corresponding to the Old Town and Wenhua syllabic consonant $/ \mathrm{y} /$ is realized with mild friction, much closer to a vowel than to a fricative. Accordingly, it is transcribed here as a labiodental approximant, / $/ \mathrm{v}$.

Allophonic variation of $/ \mathrm{v} /$ includes a realization [m] for /mvi/ (e.g. in /mụ Jzu-/ 'barley', realized [m」zł 1 ), except in careful (hyperarticulated) speech, where the realization of this syllable is [mv]. This echoes observations about other Naish languages - for instance, the same state of affairs is found in Yongning $\mathrm{Na}$ - and about neighbouring Loloish (Yi/Ngwi) languages. "In various Loloish languages some or all of the nasals occur as syllabics. In most such cases the diachronic source is syllables with a nasal initial and a high vowel; sometimes one dialect has nasal syllabics where others have nasals plus a high vowel. This could be called rhyme-gobbling" (Bradley 1989:150; see also Björverud 1998:8). Interestingly, this phenomenon does not extend to dental and velar nasals: /nvi/ and /yvi/ are pronounced as [nv] and [yv] respectively, retaining an oral realization after the initial nasal.

\subsection{Rhotic rhymes}

Pianding Naxi contrasts two rhotic rhymes, transcribed as $/ \mathfrak{\gamma} /$ and $/ \mathrm{ur} /$ in view of the comparatively back and high realization of the latter. These two rhymes correspond neatly to the rhymes $/ \varepsilon /$ and $/ \mathrm{r} /$ in Ciending, to the rhymes $/ \mathrm{\gamma} /$ and $/{ }^{\mathrm{w}} \gamma /$ in Wenhua Naxi, and to the rhymes written as $/ \Delta \mathrm{r} / \mathrm{and} / \mathrm{ur} /$ by the linguist Chang K'un, who contributed the phonetic transcriptions in the dictionary of pictograms edited by Li Lin-ts'an (Li Lin-ts'an, Chang K'un \& Ho Ts'ai 1953). The $/ \mathrm{r} / \mathrm{in} / \Lambda \mathrm{r} /$ and /ur/ is used to indicate rhotacization, not a coronal trill.

This is a highly interesting conservative feature of Pianding, Ciending and Wenhua: the opposition is lost in Old Town Naxi ("Standard Naxi"), which only has one rhotic rhyme, transcribed as / $\%$. All the items in the word list currently being compiled that have either of these two rhymes are presented in Appendix A, because information on the lexical distribution of this opposition in Pianding enriches the empirical basis for comparative-historical studies within Naish. ${ }^{7}$

While the sound correspondence is regular, the sounds themselves are different in Ciending compared with Pianding, and therefore different transcriptions are used. In Ciending, both vowels are articulated somewhat more to the front than in Pianding; of the two Ciending vowels, that further to the back is transcribed as $/ \Im \%$, and the more fronted one as $/ \varepsilon \%$. In Pianding, on the other hand, the

\footnotetext{
${ }^{7}$ For instance, inclusion of this opposition would significantly enrich the comparative data sets on Naxi rhotic rhymes assembled by $\mathrm{Li}(2014)$.

page 13
} 
further back of the two vowels is written $/ \mathrm{ur}^{\mathrm{r}}$, while the more front one is represented by the symbol $/ \curvearrowright \%$ Table 2 recapitulates correspondences between four dialects.

Table 2. Correspondences between rhotic rhymes in four Naxi dialects

\begin{tabular}{|c|c|c|c|c|c|}
\hline & & & & \\
\hline & & Pianding & Wenhua & Ciending & Old Town \\
\hline \multicolumn{2}{|c|}{ first correspondence } & $\gamma^{\prime}$ & $\gamma^{\circ}$ & $\varepsilon$ & $\gamma^{\circ}$ \\
\hline \multicolumn{2}{|c|}{ second correspondence } & $\mathrm{u}^{\sim}$ & ${ }^{w}{ }^{2}$ & $\gamma^{\circ}$ & $\gamma^{u}$ \\
\hline \multicolumn{6}{|l|}{ examples } \\
\hline English gloss & Chinese gloss & twin & $t^{\mathrm{w}} \mathrm{r}^{\mathrm{c}} \mathrm{T}$ & to1 & $t^{2} 7$ \\
\hline to close & 关（门） & 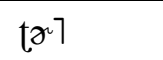 & t27 & $t \varepsilon 1$ & $t^{2} 7$ \\
\hline $\begin{array}{l}\text { to weave } \\
\text { (baskets) }\end{array}$ & 编（筐） & $\left.\mathrm{tW}^{\urcorner}\right\rceil$ & $t^{\mathrm{w}} \mathrm{r}^{\mathrm{T}}$ & to1 & $t^{2} 7$ \\
\hline
\end{tabular}

\subsection{Apicalized rhymes}

\subsubsection{Phonemic analysis}

The Old Town and Wenhua dialects of Naxi have apicalized allophones of /ur/after coronal and

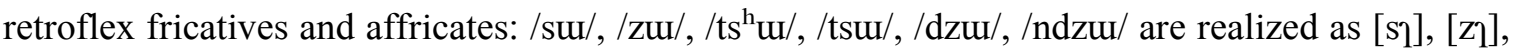

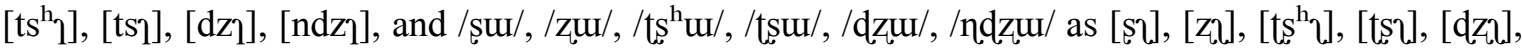
[ndzi] respectively.

The situation in Pianding Naxi is similar after retroflex fricatives and affricates, but more complex after coronal fricatives and affricates. As in Baoshan Naxi (Lǐ Zǐhè 2012), Ciending Naxi (Michaud \& Xú Jìróng 2012) and Yongning Na (Michaud, field notes), there are two sets of apicalized rhymes. These could be labelled 'front-apicalized' and 'back-apicalized' and transcribed as [?] and [1] respectively. Importantly, some words only allow a 'front-apicalized' pronunciation, others only allow a 'back-apicalized' pronunciation, and still others allow both variants. From a strictly synchronic point of view, then, there are three lexical sets. In view of the complexity of this lexical distribution, it appeared useful to set out all the examples found so far: see Table 3, divided into six parts (3a-f) on the basis of the initial consonant.

Table 3. Instances of non-retroflex apicalized rhymes in Pianding Naxi. Freely alternating forms are separated by a tilde, e.g. 'ndẓ̨̂ $\sim$ ndz

3a. Prenasalized affricated initial /ndz/

\begin{tabular}{|c|c|c|c|}
\hline English gloss & Chinese gloss & front-apicalized & $\begin{array}{l}\text { back- } \\
\text { apicalized }\end{array}$ \\
\hline chisel & 丵子 & ndz $\eta^{-1}$ & \\
\hline to dig & 挖, 用锄头锄 & ndz $\urcorner$ & \\
\hline to decide & 决定，意向 & ndz $\rceil^{-1}$ & \\
\hline
\end{tabular}




\begin{tabular}{|c|c|c|c|}
\hline English gloss & Chinese gloss & front-apicalized & $\begin{array}{l}\text { back- } \\
\text { apicalized }\end{array}$ \\
\hline to sit & 坐 & ndz!̣ $」$ & \\
\hline to cave in & 塌陷 & ndz! 」 & \\
\hline pienniu & 犏牛 & ndzḷ」 & \\
\hline to discuss & 商量 & ndzı̣」ngw & \\
\hline to borrow & 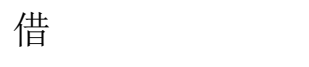 & & ndzpl 1 \\
\hline to burst apart & 振断，崩断 & & ndz 17 \\
\hline chicken's ovary & 鸡的卵巢 (子房) & & kụłndzొ̣] \\
\hline to blink & 眨眼 ～～～～～～ & & ndz’̣ ${ }^{1}$ \\
\hline tree & 树 & & ndz1̣」 \\
\hline to hate & 讨厌 & & ndzḷ $」$ \\
\hline clf: body & 身（量词） & & ndz1̣」 \\
\hline to permeate & 渗透 & & $\mathrm{ndz} \underline{1}^{-1}$ \\
\hline to sing & 唱 & \multicolumn{2}{|c|}{$\mathrm{ndz} \mathfrak{p}^{-1} \sim \mathrm{ndz} \mathfrak{p}^{-1}$} \\
\hline to eat & 吃 & \multicolumn{2}{|c|}{$\mathrm{ndz}^{-1} \sim \mathrm{ndz} \underline{1}^{-1}$} \\
\hline
\end{tabular}

3b. Voiced affricated initial /dz/

\begin{tabular}{|c|c|c|c|}
\hline English gloss & Chinese gloss & front-apicalized & $\begin{array}{l}\text { back- } \\
\text { apicalized }\end{array}$ \\
\hline a pair & 双（量词） & $\mathrm{dz} \mathfrak{l}^{-1}$ & \\
\hline existential verb & 有（树, 耳朵） & $\mathrm{dz}\rceil\rfloor$ & \\
\hline to rob & 抢 & & $\mathrm{dz} \underline{1}\rfloor$ \\
\hline to worry & 忧虑, 担心 & \multicolumn{2}{|c|}{ 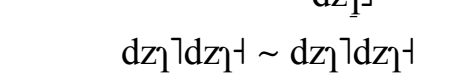 } \\
\hline
\end{tabular}

3c. Unvoiced affricated initial/ts/

\begin{tabular}{|c|c|c|c|}
\hline English gloss & Chinese gloss & front-apicalized & $\begin{array}{l}\text { back- } \\
\text { apicalized }\end{array}$ \\
\hline to install & 装, 安装 & ts? 7 & \\
\hline reported-speech part. & 据说 & tsp 7 & \\
\hline purple perilla & 紫苏 & $\operatorname{ts}]^{-1}-1$ & \\
\hline vertical & 坚 & tsp $」$ & \\
\hline to squat & 蹲 & tsp̣ $7 \mathrm{ts} ?^{-1}$ & \\
\hline dragonfly & 蜻蜓 & & kr]ts? 」 \\
\hline to cut off/block & 截（水） & & $\operatorname{ts}^{-1}$ \\
\hline to pay attention to & 理会, 理睬 & & $\mathrm{ts} \underline{1}\rfloor$ \\
\hline twenty & 二十 & & niłtsıַ」 \\
\hline to hide, to tuck away & 藏，掖（东西） & & $\mathrm{ts} \underline{1} 7$ \\
\hline
\end{tabular}




\begin{tabular}{|c|c|c|c|}
\hline English gloss & Chinese gloss & front-apicalized & $\begin{array}{l}\text { back- } \\
\text { apicalized }\end{array}$ \\
\hline fine-toothed comb & 篦子（细的） & & $\mathrm{ts} \underline{1} 7$ \\
\hline to block up & 堵, 塞 & & $\mathrm{ts} \underline{1} 7$ \\
\hline to tie & 拴, 绑, 捆 & & $\mathrm{ts}^{-1}$ \\
\hline to tell fortune & 算，算命 & & tsฐ $」$ \\
\hline fishy odour & 腥味, 膻味 & & tș $\rfloor \mathrm{n} v 1$ - \\
\hline interrogative: what & 什么 & \multicolumn{2}{|c|}{ æ-tsר̣ } \\
\hline suffix (Chinese) & 子（汉借后缀） & \multicolumn{2}{|c|}{ ts $\rceil^{-1} \sim$ ts $\underline{1}^{-1}$} \\
\hline eaves board & 封檐板 & \multicolumn{2}{|c|}{ 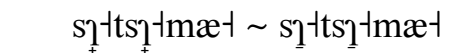 } \\
\hline bullet (borrowing) & 子弹 & \multicolumn{2}{|c|}{ ts $\nmid-1 x\rceil \sim$ ts $\rceil-1 x\rceil$} \\
\hline
\end{tabular}

3d. Aspirated affricated initial $/ \mathrm{ts}^{\mathrm{h}} /$

\begin{tabular}{|c|c|c|c|}
\hline English gloss & Chinese gloss & front-apicalized & $\begin{array}{l}\text { back- } \\
\text { apicalized }\end{array}$ \\
\hline to build & 建设, 建（房） & $\left.\mathrm{ts}^{\mathrm{h}}{ }_{1}\right\rceil$ & \\
\hline to kneel & 跪 & ts $\left.^{\mathrm{h}}\right\rceil_{1}$ & \\
\hline to excavate & 端（锅），挖（树） & $\operatorname{ts}^{\mathrm{h}} \underline{1-1}_{-1}^{-1}$ & \\
\hline ploughshare & 犁铧 & ts $^{\mathrm{h}} \underline{1}_{1-1}^{-1}$ & \\
\hline ghost & 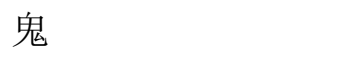 & ts $\left.^{\mathrm{h}} \underset{\uparrow}{ }\right\rfloor$ & \\
\hline fine, thin & 细（树、体型细小） & $\mathrm{ts}^{\mathrm{h}} \uparrow$ & \\
\hline dry season & 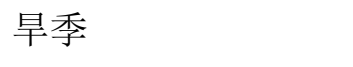 & ts $^{\mathrm{h}} q^{-1}$ & \\
\hline uncomfortable & 不舒服, 不对劲 & $\left.\operatorname{ts}^{\mathrm{h}} \prod^{+}-\mathrm{ts}^{\mathrm{h}}{ }^{\mathrm{h}}\right\rfloor$ & \\
\hline piglet & 年猪 ～～～～～ & ts $\left.\left.{ }^{\mathrm{h}}\right\rceil \underline{t b u}\right\rfloor$ & \\
\hline to kick & 踢 & $\mathrm{ts}^{\mathrm{h}}{ }^{+} \underline{1}^{-1}$ & \\
\hline garden peas & 踠豆 & ts $^{\mathrm{h}} ?^{\mathrm{t}} 7 \mathrm{ts}^{\mathrm{h}} \mathrm{q}^{-1}$ & \\
\hline hot & 热 & & $\mathrm{ts}^{\mathrm{h}} \underline{1-1}^{-1}$ \\
\hline to boil & 涨水, 沸腾 & & $\left.\operatorname{ts}^{\mathrm{h}}{ }_{\underline{1}}\right\rfloor \mathrm{t}^{\mathrm{h}} v-1$ \\
\hline to scoop up, to dredge & 捞（水中） & & $\left.\mathrm{ts}^{\mathrm{h}}{ }^{\mathrm{p}}\right\rfloor$ \\
\hline to sever, to cut off & 锯断, 切断, 割断 & & $\left.\operatorname{ts}^{\mathrm{h}} \underline{1}\right\rceil$ \\
\hline scissors & 剪刀 & & $\left.\mathrm{ts}^{\mathrm{h}}{ }^{1}-\mathrm{tte}\right\rfloor$ \\
\hline to pinch & 掐 & & $\left.\mathrm{ts}^{\mathrm{h}} \underline{1}\right\rceil$ \\
\hline to drop; to put into & 掉（水，草丛等） & & $\left.\operatorname{ts}^{\mathrm{h}} \underline{\underline{1}}\right\rfloor$ \\
\hline Chinese catalpa & 楸树 & \multirow{2}{*}{\multicolumn{2}{|c|}{ 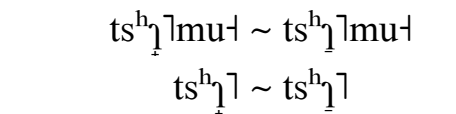 }} \\
\hline sheep & 羊 & & \\
\hline
\end{tabular}


3e. Unvoiced fricative initial /s/

\begin{tabular}{|c|c|c|c|}
\hline English gloss & Chinese gloss & front-apicalized & $\begin{array}{l}\text { back- } \\
\text { apicalized }\end{array}$ \\
\hline morning & 早晨 & mutsp̣ttu-1 & \\
\hline to sift; to choose & 筛选, 选择 & $\mathrm{s} \mathfrak{l}\rfloor$ & \\
\hline to revive & 复活, 恢复 & sp̣ 7 & \\
\hline to pick up & 捡, 拾 & $\mathrm{s} 17$ & \\
\hline to mold & 塑（像） & $\mathrm{s} 17$ & \\
\hline to ponder & 思考 & sp̣tndụt & \\
\hline to wipe & 擦, 揩拭 & sp̣ 7 & \\
\hline three & 三 & $\mathrm{s}\rceil\rfloor$ & \\
\hline wool & 羊毛 & ș̣-1 & \\
\hline liver & 肝 & & spl 1 \\
\hline to shave & 刮, 剃 & & s!1 1 \\
\hline to know & 知道 & & sq-1 \\
\hline to like & 喜欢, 上瘾 & & $\mathrm{s}^{-1}$ \\
\hline fog & 雾 & & $\left.\mathrm{c}^{\mathrm{h}}{ }^{\mathrm{i}}\right\rceil \mathrm{s} \mathfrak{1}^{-1}$ \\
\hline to itch & 痒（被毛毛虫） & & $\mathrm{s}^{-1}$ \\
\hline raw (meat) & （肉）不熟的 & & $\mathrm{s}\rfloor\rfloor$ \\
\hline to be shy & 认生, 怕生 & & $\mathrm{s} \mathfrak{l}\rfloor$ \\
\hline onomatopoeic & 沙哑（声音） & \multicolumn{2}{|c|}{$\mathrm{s} \mathfrak{1} 7 \sim \mathrm{s} \underline{1} 1$} \\
\hline back & 脊，脊背 & \multicolumn{2}{|c|}{ 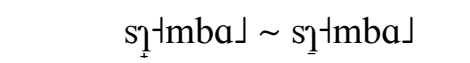 } \\
\hline to sharpen & 磨（刀） & \multicolumn{2}{|c|}{$\mathrm{s}_{1}^{-1} \sim \mathrm{s}_{1}^{-1}$} \\
\hline bladder & 膀胱 & \multicolumn{2}{|c|}{ 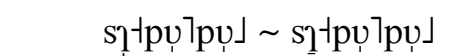 } \\
\hline wood & 木头 & \multicolumn{2}{|c|}{$\mathrm{spl}_{1}^{-1} \sim \mathrm{s} \mathfrak{x}^{-1}$} \\
\hline fruit & 水果 & \multicolumn{2}{|c|}{ 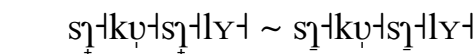 } \\
\hline paper & 纸 & \multicolumn{2}{|c|}{ 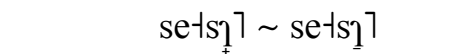 } \\
\hline to wean & 断奶 & \multicolumn{2}{|c|}{$\mathrm{s} 1] \sim \mathrm{s} \underline{1} 7$} \\
\hline
\end{tabular}

3f. Voiced fricative initial /z/

\begin{tabular}{|c|c|c|c|}
\hline English gloss & Chinese gloss & front-apicalized & $\begin{array}{l}\text { back- } \\
\text { apicalized }\end{array}$ \\
\hline to shrink & 缩（水）,皱（眉） & $\mathrm{z} 1\rceil$ & \\
\hline to scratch & 挠，抓 & $\mathrm{zl}\rfloor$ & \\
\hline highland barley & 青稞 & $z\rceil^{-1}$ & \\
\hline life & 命 & $\mathrm{z}\rceil^{-1}$ & \\
\hline to push down & 垫, 压 & & $\mathrm{z} \mathfrak{1}\rfloor$ \\
\hline
\end{tabular}




\begin{tabular}{|c|c|c|}
\hline to endure & 憋（尿）；忍耐 & $\mathrm{z}_{1}^{-1}$ \\
\hline younger brother & 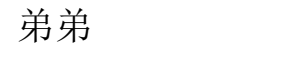 & $\operatorname{gu}-\mathrm{z}^{-1}$ \\
\hline classifier for times & 次, 次数 & $\mathrm{z} \mathfrak{l}\rfloor \sim \mathrm{z} \mathfrak{l}\rfloor$ \\
\hline button & 纽扣 & $\mathrm{z} 1+1 \mathrm{Y}-\sim \mathrm{z} 1-1 \mathrm{Y}-1$ \\
\hline grass & 草 ～～～～～～～ & $\mathrm{z}_{1}^{-1} \sim \mathrm{z}_{1}^{-1}$ \\
\hline dizzy & 头昏, 头晕 & $\mathrm{z}_{1}^{-\dagger} \sim \mathrm{z}^{-1}$ \\
\hline knife & 刀子 & $\left.\mathrm{z}]^{-1 \mathrm{t}^{\mathrm{h}} \mathrm{e}} \sim \sim \mathrm{z}\right]^{-1 \mathrm{t}^{\mathrm{h}} \mathrm{e}}$ \\
\hline
\end{tabular}

The distribution of lexical items between the front-apicalized and back-apicalized sets is relatively balanced, revealing that this is a well-established opposition, not a marginal one.

The phonetic realization of apicalized rhymes does not provide any clear hints as to their origin or their phonemic analysis. For instance, the Mandarin syllable written as $z i$ in Pinyin is realized as [ts]], and phonemicized as /tsi/; its phonetic realization does not seem significantly different from that of the Naxi syllable written as zee in Naxi Pinyin, and phonemicized as /tsu/.

Indications on phonemic analysis are to be drawn from the inventory of syllables found in the language variety under investigation. In the case of Wenhua Naxi, interpretation as /i/ for apical vowels was ruled out by the existence of syllables such as /si/, e.g. /sit/ 'poor, destitute' (phonetically [si-]), contrasting with apicalized [s-1] 'to know', which is analyzed as /sut-/ (likewise in Eya Naxi: Zēng Xiăopéng 2011:20-25). In the case of Pianding, the syllables corresponding to Wenhua fricative plus /i/ have alveolo-palatal initials (e.g. 'poor' is / $\mathrm{it} /$ ), so the range of possible phonemic interpretations for [?] and [1] is especially vast: the two apicalized vowels are in complementary distribution with five other vowels, $/ \mathrm{u} /, / \gamma /, / \mathrm{i} /, / \mathrm{\gamma} /$ and $/ \mathrm{ur} /$. This is a case where several options for phonemic analysis. are open In Ciending, where the situation is similar to Pianding in terms of phonetic realization, native speaker Xu Jirong chose to interpret the 'frontapicalized' vowel [1] sound as an allophone of /u/, as in Old Town Naxi and Wenhua Naxi, and the 'back-apicalized' vowel sound as an allophone of $/ \gamma /$ - a decision which was respected in joint work on this topic (Michaud \& Xu Jirong 2012). The authors of the present paper tried to convince themselves of the advantages of one analysis over the other, but eventually concluded that there was no substantial evidence in favour of either of these solutions. Instead, we choose to grant phonemic status to both $/ \mathfrak{q}$ and $/ \mathfrak{l} /$. This can be criticized as leaving the phoneme inventory with a somewhat overly-phonetic slant. This uneconomical choice has a major advantage, however. It draws attention to a key fact of Naxi phonology: as initials and rhymes become tightly coarticulated within syllables that have an essentially CV structure, the ties between allophones become laxer, and oppositions tend to be between syllables rather than between phonemes. This offers fertile ground for psycholinguistic experiments, to investigate topics such as the degree of perceived proximity between a given sound

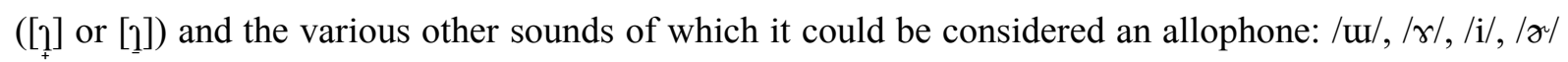
and $/ \mathrm{ur} \%$. One of the aims of the present article is to bring out research topics such as this one. 
Another option for the phonemic analysis of [1]] and [1]], chosen in a study of Eya Naxi (Zēng Xiăopéng 2011:20-25), consists in describing one of the two rhymes as tense and the other as lax. This suggestion appears to be based partly on the continuing influence of a suggestion by Yang Huandian that, since all Yi (Loloish, Ngwi) languages have a tense/lax contrast on vowels, Naxi must have one too (Yáng Huàndiăn 1984). The latter argument loses some of its strength, however, in view of the lack of demonstrated regular correspondences between Naxi and Yi, already pointed out by Bradley (1975). ${ }^{8}$ From a phonetic point of view, Yang Huandian's hypothesis was not confirmed by an electroglottographic analysis of Wenhua Naxi (Michaud 2005:228), which revealed overlapping ranges of open quotient - a measurement that provides an indication on the degree of vocal fold abduction (Henrich et al. 2004) - for the vowels described by Yang as 'tense' and 'lax'. Expert listening and preliminary electroglottographic measurements did not reveal evidence of any salient differences at the laryngeal level for Pianding Naxi either.

Leaving aside the issue of its phonemic interpretation, the opposition of [1] and [1] is of great interest for diachronic research. Knowledge of the lexical distribution of this opposition now allows for improvements over earlier comparative work - to date, essentially Jacques et al. (2011) and Lǐ Zǐhè (2013). For instance, 'to tie, to attach' (拴) is simply /tsut// in the language varieties that were taken into account in earlier reconstruction work (Naxi /tsu-t/, $\mathrm{Na} / \mathrm{tsu} 1 /$, Laze /tsu-1/), leading to a reconstruction as *tsi (Jacques \& Michaud 2011:471). Recognition of the opposition among apicalized vowels will allow for a more fine-grained reconstruction.

\subsubsection{Cases of devoicing of apicalized rhymes}

The syllable /suJ / is entirely voiceless in some contexts. This phenomenon is conditioned by both phonological and morphological factors. The phonological condition on the devoicing of $/ \mathrm{u} / \mathrm{after} / \mathrm{s} /$ is that it only occurs when the syllable carries L tone; the morphological condition is that it only

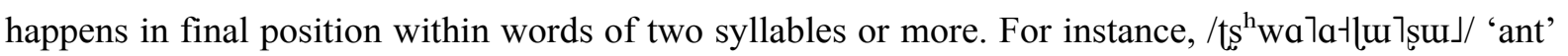

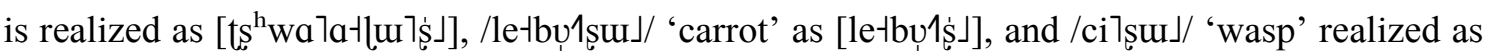

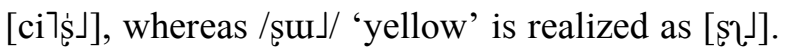

This devoicing process provides a useful test for determining whether a given word is treated as a single lexeme, or as a combination of two. Etymologically, /le-bụ̂sud/ 'carrot' consists of /le-bụ// 'radish' plus the adjective /suJ/ 'yellow'. But the fact that the final syllable is devoiced strongly suggests that trisyllabic /lełbụ/șuJ/ 'carrot' is now treated as a single lexeme.

\footnotetext{
${ }^{8}$ The search for correspondences between Naxi/Naish and Yi/Loloish nonetheless continues, witness the recent Ph.D. dissertation of Li Zihe (Ľ̌ Zǔhè 2013). Note that, while different researchers' assumptions about language relatedness influences their search for outside comparanda and their interpretation of the correspondences in terms of proto-phonemes, the results of the 'grassroots' comparative work which is essential to historical linguistics - establishing correspondences between undoubtedly related dialects - is valid irrespective of the assumptions made about family trees at higher levels.
} 


\subsubsection{A marginal syllable: /hĩ/}

The syllable /hĩ/ (nasalized throughout) is attested only once in our data, in a phrase describing sillysounding laughter: /hĩ $\sim$ hĩ -beł zæJ/, EXPRESSIVE + ADVERBIALIZER + 'to laugh', meaning 'to laugh with silly laughter'. Interestingly, this syllable, which looks onomatopoeic in Pianding, is part of the phonemic inventory of various Naish varieties, including those of Fengke, Yongning, and Muli (Michaud \& Jacques 2012). However, the authors are not aware of any contact of Pianding Naxi speakers with speakers from these areas, which could have contributed to (re-)introducing this syllable at the margin of the system. This syllable is not indicated in Table 4, saving an extra line in the table.

\section{The tone system}

The tone system of Naxi is essentially based on three levels, L(ow), M(id) and H(igh), which are easy to identify, and which are identical across dialects such as Old Town, Wenhua and Pianding. Falling contours never play a distinctive role in the phonology or the morphology; on the other hand, distinctive rising contours are found. A striking asymmetry in Naxi dialects is that $\mathrm{LH}$ and $\mathrm{MH}$ contours are distinguished at the sentence level but neutralized at the lexical level. In Pianding, as in Wenhua (Michaud 2006b; Michaud \& He Xueguang 2007), there are productive processes creating rising contours on low- or mid-tone syllables, as in example (1).

(1) $\left[\mathrm{du}-1-\mathrm{ni} 1 \mathrm{fY}^{-1}\right]$

dut $\quad$ nit $\quad 1$

one day only (reduced form of $/ \mathrm{ta} 7 /$ ) EXISTENTIAL_VERB

'There is only one day left.'

The resulting contour in (1) is $\mathrm{MH}$; there also exist $\mathrm{LH}$ contours, derived from L-tone syllables. In the lexicon, however, there is only one rising tone. Words carrying a rising lexical tone include (i) a few tokens of non-borrowed vocabulary, such as the set of COLLECTIVE pronouns $/ \mathrm{ya} 1 /, / \mathrm{na} 1 /, / \mathrm{t}^{\mathrm{h}} \mathrm{a} 1 /$ (from $1^{\text {st }}$ to $3^{\text {rd }}$ person), referring to someone's extended family (clan), and (ii) numerous Chinese loanwords, such as /la1tsp̣1/ 'candle' (làzhú 蜡烛). These items are written here with tone 1 (3 to 5 on the Chao scale). It must be made clear, however, that there is no opposition between $\mathrm{LH}$ and $\mathrm{MH}$ tones at the lexical level and, as such, 1 is a somewhat arbitrary representation, as either notation would have been acceptable. Some syllables that currently carry a rising tone originate etymologically in a L tone, others in a M tone. For instance, the word 'carrot' (already mentioned in

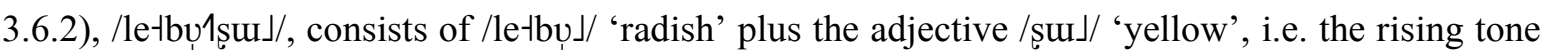
on the syllable $/ \mathrm{bu} 1 /$ is the product of the modification of a $\mathrm{L}$ tone. The second author's intuition is that the tone of the second syllable in 'carrot' is not phonologically different from that of the second syllable in /br-bor// 'lovely little piglet', which clearly originates in a M tone. So we adopt the same 
notation for the rising tones in /br-tbr // 'lovely little piglet' and /le-bụ1swal/ 'carrot', despite the etymological evidence that one derives from a $\mathrm{L}$ tone and the other from a $\mathrm{M}$ tone.

Interesting evidence comes from a few low-tone words, such as the intensive 'very', /yæ $\mathrm{J}$, which are habitually realized with a rise, as / $\mathfrak{f} / /$. This habitual rise is due to intonational emphasis via a rising contour (Michaud 2006b). This rise is not always present, thus displaying a synchronic alternation between a L tone and a LH tone. Were the L-tone realization /yæJ/, currently rare, to disappear entirely, it would be interesting to see whether the LH tone of / fæ// would change to MH (following the general pattern of neutralization of LH and MH in the lexicon), or whether it would introduce a fifth lexical tone: LH. One factor which reduces the likelihood of the development of an opposition between two rising lexical tones in Pianding Naxi is the current situation of gradual language shift to (Southwestern) Mandarin Chinese, which does not have such an opposition. (On the hybrid properties of the tone system of Naxi - three level tones and one contour -, see Michaud 2013b.)

\section{Inventory of syllables}

Table 4 provides an inventory of Pianding Naxi syllables, in phonemic notation. The code ' $\mathrm{CH}$ ' indicates that the syllable at issue is only found in Chinese loanwords, and the code ' $O$ ' that it is found only in onomatopoeic words. Glides are considered as part of the rhyme. All the syllables in Table 4 are exemplified in Appendix B.

This table provides a bird's-eye view of the entire system. It brings out salient facts, such as (i) the relatively high number of gaps, which calls for a study using the tools of historical linguistics; (ii) the high number of onomatopoeic coinages: onomatopoeic pairings of initials and rhymes into new combinations; and (iii) the huge influence of recent Chinese loanwords, which introduce many new combinations of vowels with semivowels. As an illustration of the tensions within the system introduced by loanwords: among early loanwords, /jur $1 /$, for 'drug, chemical' (in /ho Jjur $1 /$ 'gunpowder', huǒyào 火药), is the only attested example of $/ \mathrm{j} /+/ \mathrm{ur} /$ in the system. Adding $/ \mathrm{jur} /$ to Table 4, where semivowels are represented as part of the rhyme, would require the creation of an additional column for the entire table, which would be empty save for the "zero initial" line. For the sake of typographical convenience, /jur/ is simply left out of the table - a compromise which highlights the need for a distinct study focusing on Chinese loans and their respective degrees of integration within the system. From a diachronic point of view, methods to tease apart the various layers have been successfully applied to languages of the area (see in particular Sagart \& Xu Shixuan 2001). 
Table 4. An inventory of Pianding Naxi syllables, in phonemic notation.

\begin{tabular}{|c|c|c|c|c|c|c|c|c|c|c|c|c|c|c|}
\hline & $\mathrm{i}$ & $\mathrm{Y}$ & 1 & 1 & u & ur & $\gamma^{\nu}$ & $\mathrm{u}$ & $\mathrm{e}$ & $\gamma$ & vִ & o & $æ$ & $\mathrm{a}$ \\
\hline $\mathrm{p}^{\mathrm{h}}$ & $p^{h_{i}}$ & $p^{h} Y$ & & & $\mathrm{p}^{\mathrm{h}} \mathrm{u}$ & & $\mathrm{p}^{\mathrm{h}} \mathrm{\gamma}^{\mathrm{u}}$ & $\mathrm{p}^{\mathrm{h}} \mathrm{u}$ & $\mathrm{p}^{\mathrm{h}} \mathrm{e}$ & $\mathrm{p}^{\mathrm{h}} \gamma C H$ & $\mathrm{p}^{\mathrm{h}} \underline{v}$ & $\mathrm{p}^{\mathrm{h}} \mathrm{o} C H$ & $\mathrm{p}^{\mathrm{h}} \mathfrak{x}$ & $\mathrm{p}^{\mathrm{h}} \mathrm{a}$ \\
\hline $\mathrm{p}$ & pi & py & & & pur & pur & pro & $\mathrm{pu}$ & pe & pr & pu & po & pæ & $\mathrm{pa}$ \\
\hline $\mathrm{b}$ & bi & by & & & bu & & $\mathrm{br}$ & $\mathrm{bu}$ & be & br & bu & & bæ & $\mathrm{ba}$ \\
\hline $\mathrm{mb}$ & mbi & $\mathrm{mby}$ & & & mbu & & $m b \gamma^{\circ}$ & $\mathrm{mbu}$ & mbe & $\mathrm{mbr}$ & mbv & mbo $O$ & mbæ & $\mathrm{mba}$ \\
\hline $\mathrm{m}$ & $\mathrm{mi}$ & $\mathrm{my}$ & & & mu & & $m \gamma^{\circ}$ & $\mathrm{mu}$ & me & $\mathrm{m} \gamma$ & $m v$ & mo & $m æ$ & $\mathrm{ma}$ \\
\hline $\mathrm{f}$ & & & & & fur $O$ & & fəo $O$ & & fe $C H$ & $\mathrm{f \gamma} C H$ & fụ & fo $C H$ & $\mathrm{fæ}$ & fa $C H$ \\
\hline $\mathrm{v}$ & & & & & vur $O$ & & var $O$ & & ve $C H$ & & & & væ $C H$ & \\
\hline $\mathrm{t}^{\mathrm{h}}$ & $\mathrm{t}^{\mathrm{h}_{\mathrm{i}}}$ & $\mathrm{t}^{\mathrm{h}} \mathrm{Y}$ & & & $t^{\mathrm{h}} u$ & $t^{\mathrm{h}} u r$ & $\mathrm{t}^{\mathrm{h}} \mathrm{\gamma}^{\mathrm{u}}$ & & $\mathrm{t}^{\mathrm{h}} \mathrm{e}$ & & $\mathrm{t}^{\mathrm{h}} w$ & $\mathrm{t}^{\mathrm{h}} \mathrm{O}$ & $\mathrm{t}^{\mathrm{h}} \mathfrak{x}$ & $\mathrm{t}^{\mathrm{h}} \mathrm{a}$ \\
\hline $\mathrm{t}$ & $\mathrm{ti}$ & ty & & & tw & tur & to & tu $O$ & te $C H$ & & tụ & to & tæ & ta \\
\hline$d$ & di & $d y$ & & & du & dur & $\mathrm{d} x^{u}$ & & & & $d v$ & do & $\mathrm{d} æ$ & $\mathrm{da}$ \\
\hline nd & ndi & ndy & & & ndu & ndur & ndr & ndu & nde & & ndu & ndo & ndæ & nda \\
\hline $\mathrm{n}$ & ni & & & & nu & nur & $n r^{\circ}$ & & ne & & nu & no & næ & na \\
\hline $\mathrm{n}$ & ni & $\mathrm{ny}$ & & & & & & & ne $C H$ & nr & & & næ & na \\
\hline y & & & & & & & & & ye $C H$ & gr & nụ & & yæ $C H$ & ya \\
\hline 1 & li & $1 \mathrm{y}$ & & & lu & lur & $1 \gamma^{2}$ & lu & le & lr $C H$ & $1 v$ & lo & $1 æ$ & la \\
\hline$t^{h}$ & & $\operatorname{ts}^{\mathrm{h}} \mathrm{Y}$ & ts $^{\mathrm{h}}$ ? & ts $^{\mathrm{h}} \underline{1}$ & & & & & $\mathrm{ts}^{\mathrm{h}} \mathrm{e}$ & & & $t^{\mathrm{h}} \mathrm{o}$ & ts $^{\mathrm{h}} \mathfrak{x}$ & $t^{\mathrm{h}} \mathrm{a}$ \\
\hline ts & & tsy & ts & $\mathrm{ts} \underline{1}$ & & & & & tse & & & tso & tsæ & tsa \\
\hline dz & & dey & $\mathrm{d}_{1}$ & $d_{1}$ & & & & & de & & & & ckæ & \\
\hline ndz & & ndey & ndz) & $\mathrm{ndz} \mathbf{l}_{1}$ & & & & & ndze & & & ndzo & ndææ & ndza \\
\hline $\mathrm{s}$ & si & SY & sp̣ & spl & & & & & se & & & so & sæ & sa \\
\hline $\mathrm{z}$ & $\mathrm{zi}$ & $\mathrm{ZY}$ & z) & $\mathrm{z} 1$ & & & & & ze & & & zo & $\mathrm{zæ}$ & $\mathrm{za}$ \\
\hline
\end{tabular}




\begin{tabular}{|c|c|c|c|c|c|c|c|c|c|c|c|c|c|}
\hline & $\mathrm{i}$ & $\mathrm{Y}$ & $\underline{1}$ & $\mathrm{u}$ & $\mathrm{ur}$ & $\gamma^{u}$ & $\mathrm{u}$ & $\mathrm{e}$ & $\gamma$ & v & $\mathrm{o}$ & $æ$ & $\mathrm{a}$ \\
\hline $\mathrm{ts}^{\mathrm{h}}$ & & & & $t^{\mathrm{h}} \mathrm{u}$ & $t^{\mathrm{h}}{ }^{\mathrm{u}}$ & $\operatorname{ts}^{\mathrm{h}} \boldsymbol{\gamma}^{\mathrm{c}}$ & $\operatorname{tss}^{\mathrm{h}} \mathrm{u}$ & $\mathrm{ts}^{\mathrm{h}} \mathrm{e} C H$ & $\operatorname{ts}^{\mathrm{h}} \gamma$ & $\operatorname{tss}^{\mathrm{h}} v$ & $\mathrm{ts}^{\mathrm{h}} \mathrm{o}$ & & \\
\hline ts & & & & tșu & tsur & tso & tșu & tse $C H$ & ts $\gamma$ & tș & & & \\
\hline $\mathrm{dz}$ & & & & dzuu & dz̧ur & dzo & dzu & & dzr & dzu & & & \\
\hline ndz & & & & ndzu & ndzur & ndza & ndzu & & & ndzu & & & \\
\hline S & & & & șu & șur & $s \gamma^{\circ}$ & şu & se $C H$ & sr & su & & & \\
\hline $\mathrm{z}$ & & & & zuU & zur & $\mathrm{z} \partial^{\circ}$ & $\mathrm{zu}$ & ze $C H$ & $z_{r}$ & zu & & & za $C H$ \\
\hline $\mathrm{k}^{\mathrm{h}}$ & $\mathrm{k}^{\mathrm{h}_{\mathrm{i}} O}$ & & & $\mathrm{k}^{\mathrm{h}} \mathrm{u}$ & $\mathrm{k}^{\mathrm{h}} \mathrm{ur}$ & $\mathrm{k}^{\mathrm{h}} \gamma^{\gamma} O$ & $\mathrm{k}^{\mathrm{h}} \mathrm{u}$ & $\mathrm{k}^{\mathrm{h}} \mathrm{e} C H$ & $\mathrm{k}^{\mathrm{h}} \gamma$ & $\mathrm{k}^{\mathrm{h}} v$ & $\mathrm{k}^{\mathrm{h}} \mathrm{O}$ & $\mathrm{k}^{\mathrm{h}} \mathfrak{}$ & $\mathrm{k}^{\mathrm{h}} \mathrm{a}$ \\
\hline $\mathrm{k}$ & ki $O$ & & & $\mathrm{kw}$ & kur & $\mathrm{k} \gamma^{\circ}$ & $\mathrm{ku}$ & ke $C H$ & $\mathrm{kr}$ & $\mathrm{kv}$ & ko & $\mathrm{kæ}$ & $\mathrm{ka}$ \\
\hline g & & & & gur & & & $\mathrm{gu}$ & & gr & $g v$ & & & \\
\hline $\mathrm{yg}$ & ygi $O$ & & & ygu & & & ggu & & ggr & ygu & ygo & ygæ & yga \\
\hline $\mathrm{h}$ & hi & hy & & hw & hur & & hu & he & hr & & ho & hæ & ha \\
\hline ç & çi & çY & & & çur & & & çe $C H$ & çr & & & çæ $C H$ & ça \\
\hline$c^{h}$ & $c^{h_{i}}$ & $c^{h} Y$ & & & $c^{\mathrm{h}^{\mathrm{ur}}} \mathrm{CH}$ & $\mathrm{c}^{\mathrm{h}} \gamma^{\mathrm{u}}$ & & & $c^{\mathrm{h}} \gamma$ & & & $\mathrm{c}^{\mathrm{h}} \mathfrak{x} C H$ & $\mathrm{c}^{\mathrm{h}_{\mathrm{a}}} C H$ \\
\hline $\mathrm{c}$ & ci & $\mathrm{cY}$ & & & cur & $\mathrm{cr}^{\mathrm{r}}$ & & ce $C H$ & $\mathrm{cr}$ & & & $\mathfrak{c æ} C H$ & ca $C H$ \\
\hline f & fi & fY & & & & & & fe & $f^{\gamma}$ & & & 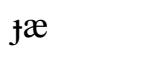 & fa \\
\hline $\mathrm{nf}$ & $\mathrm{nfi}$ & $\mathrm{nfY}$ & & & & $\mathrm{nfr}$ & & & $n_{f} \gamma$ & & & & \\
\hline$t_{6}{ }^{h}$ & $t_{6}{ }^{h} i$ & & & & & & & & $\mathrm{tc}^{\mathrm{h}} \gamma \mathrm{CH}$ & & & $\mathrm{tc}_{6}^{\mathrm{h}} \mathfrak{C} H$ & $\mathrm{tc}^{\mathrm{h}} \mathrm{a} C H$ \\
\hline te & tçi & & & & & & & & $\operatorname{tcr} \mathrm{CH}$ & & & tcæ $C H$ & tça $O$ \\
\hline $\mathrm{d} z$ & dzi & & & & & & & & & & & & \\
\hline $\mathrm{ndz}$ & ndzi $O$ & & & & & & & & & & & & \\
\hline$\varnothing$ & $\mathrm{i}$ & $\mathrm{Y}$ & & $\mathrm{u}$ & & $\gamma^{\sim} C H$ & $\mathrm{u}$ & $\mathrm{e}$ & $\gamma$ & v & o & $æ$ & $\mathrm{a}$ \\
\hline
\end{tabular}




\begin{tabular}{|c|c|c|c|c|c|c|c|c|c|c|}
\hline & we & jwe & wr & jwæ & wæ & wa & $\mathrm{j} \gamma$ & je & $\mathrm{j} \mathfrak{}$ & ja \\
\hline $\mathrm{p}^{\mathrm{h}}$ & & & & & & & $\mathrm{p}^{\mathrm{h}} \mathrm{j} \gamma$ & $\mathrm{p}^{\mathrm{h}}$ je $C H$ & $\mathrm{p}^{\mathrm{h}} \mathrm{jæ} C H$ & $\mathrm{p}^{\mathrm{h}}$ ja $C H$ \\
\hline $\mathrm{p}$ & & & & & & & pj $\gamma$ & & pjæ $C H$ & pja $C H$ \\
\hline $\mathrm{b}$ & & & & & & & bj $\gamma$ & & & \\
\hline $\mathrm{mb}$ & & & & & & & $\mathrm{mbj} \gamma$ & & mbjæ $O$ & mbja $O$ \\
\hline $\mathrm{m}$ & & & & & & & $\mathrm{mjr}$ & & mjæ $C H$ & mja $C H$ \\
\hline$f$ & & & & & & & & & & \\
\hline $\mathrm{v}$ & & & & & & & & & & \\
\hline$t^{h}$ & & & & & $t^{h} w \mathfrak{~}$ & & $\mathrm{t}^{\mathrm{h}} \mathrm{j} \gamma$ & $\mathrm{t}^{\mathrm{h}} \mathrm{je} C H$ & $\mathrm{t}^{\mathrm{h}_{\mathrm{j}} æ C H}$ & $\mathrm{t}^{\mathrm{h}}$ ja $C H$ \\
\hline $\mathrm{t}$ & & & & & twæ $C H$ & & $\operatorname{tj} \gamma$ & & tjæ $C H$ & tja $C H$ \\
\hline $\mathrm{d}$ & & & & & & & $\operatorname{dj} \gamma$ & & & \\
\hline nd & & & & & ndwæ $O$ & & ndjr & & & \\
\hline $\mathrm{n}$ & & & & & & & & & & \\
\hline $\mathrm{n}$ & & & & & & & $c f \mathrm{n} \gamma$ & & $c f$ næ & $c f$ na \\
\hline$\eta$ & & & & & & & & & & \\
\hline 1 & & & lwr & & lwæ $C H$ & & $\mathrm{lj} \gamma$ & lje $C H$ & ljæ $C H$ & $\operatorname{lja} O$ \\
\hline$t^{h}$ & $\mathrm{ts}^{\mathrm{h}}$ we $C H$ & & & & $\mathrm{ts}^{\mathrm{h}} \mathrm{w} æ O$ & & & & & \\
\hline ts & tswe $C H$ & & & & tswæ $C H$ & & & & & \\
\hline d & & & & & & & & & & \\
\hline nd & & & & & & & & & & \\
\hline s & swe & & & & swæ $O$ & & & sje $C H$ & sjæ $C H$ & \\
\hline $\mathrm{z}$ & & & & & zwæ $O$ & & & & & \\
\hline
\end{tabular}

page 24 


\begin{tabular}{|c|c|c|c|c|c|c|c|c|c|c|}
\hline & we & jwe & wr & jwæ & wæ & wa & $\mathrm{j} \gamma$ & je & jæ & ja \\
\hline$t s^{h}$ & ts $^{\mathrm{h}}$ we $C H$ & & & & $\mathrm{ts}^{\mathrm{h}} \mathrm{w} æ C H$ & $\operatorname{ts}^{\mathrm{h}} \mathrm{wa}$ & & & & \\
\hline ts & tswe $C H$ & & & & tswæ $C H$ & tswa & & & & \\
\hline $\mathrm{dz}$ & & & & & & & & & & \\
\hline ndz & ndzwe & & & & & ndzwa & & & & \\
\hline S & swe & & & & swæ $C H$ & swa & & & & \\
\hline $\mathrm{z}$ & zwe & & & & & zwa & & & & \\
\hline $\mathrm{k}^{\mathrm{h}}$ & $\mathrm{k}^{\mathrm{h}}$ we $C H$ & & $\mathrm{k}^{\mathrm{h}} \mathrm{wr}$ & & $\mathrm{k}^{\mathrm{h}} \mathrm{wæ}$ & $\mathrm{k}^{\mathrm{h}} \mathrm{wa}$ & & & & \\
\hline $\mathrm{k}$ & kwe $C H$ & & kwr & & kwæ $C H$ & kwa & & & & \\
\hline g & & & & & & & & & & \\
\hline gg & & & ygwr & & ygwæ $O$ & & & & & \\
\hline $\mathrm{h}$ & hwe & & hwr $C H$ & & hwæ $C H$ & hwa & & & & \\
\hline ç & & & çwe $C H$ & & çwæ $C H$ & & & & & \\
\hline$c^{h}$ & & & $\mathrm{c}^{\mathrm{h}}$ we $C H$ & & $\mathrm{c}^{\mathrm{h}} \mathrm{wæ} C H$ & & & & & \\
\hline c & & & cwe $C H$ & & cwæ $C H$ & & & & & \\
\hline $\mathrm{f}$ & & & & & & & & & & \\
\hline $\mathrm{nf}$ & & & & & & & & & & \\
\hline $16^{\mathrm{h}}$ & & & & & & & & & & \\
\hline th & & & & & & & & & & \\
\hline $\mathrm{d} z$ & & & & & & & & & & \\
\hline ndz & & & & & & & & & & \\
\hline$\varnothing$ & we $C H$ & jwe $C H$ & wr & jwæ $C H$ & wæ & wa & jr & & $\mathrm{jæ}$ & ja \\
\hline
\end{tabular}




\section{Conclusion}

After sifting through substantial amounts of Pianding Naxi data (a list of about 3,000 words, and a life story of 1,200 words), the phonemic system of this heretofore unstudied dialect can now be considered to be established with a good degree of certainty. The highlights of this study in terms of contributions to Naxi dialectology consist of the observation of (i) two apicalized vowels, $/ \mathfrak{1} /$ and $/ \mathfrak{1} /$, and (ii) two rhotic vowels, $/ \mathrm{r} /$ and $/ \mathrm{ur} /$, compared with only one apicalized vowel and one rhotic vowel in Old Town Naxi, the best-described Naxi dialect to date. Information on the lexical distribution of these oppositions enriches the empirical basis for comparative-historical studies. Among other perspectives for future work, the strong allophonic variation found in Pianding Naxi would well warrant an experimental phonetic study. After monosyllabicization (an evolution common to many Asian languages; see Brunelle \& Pittayaporn 2012; Michaud 2012), phonologically rich monosyllables tend to erode further into syllables made up simply of a consonant, an optional glide, a vowel (or syllabic consonant) and a tone. At this stage in the evolutionary process, as illustrated by Naish languages in general, coarticulation tends to become so strong as to raise issues for phonemic analysis.

\section{Acknowledgments}

Many thanks to two anonymous reviewers and to Roselle Dobbs for insightful and constructive criticism. The present study was initiated during a stay of the second author at the International Research Institute MICA (Hanoi, Vietnam) from April to June 2014; we are grateful to Hanoi University of Science and Technology and Yunnan University of Nationalities for making this stay possible. Financial support from Agence Nationale de la Recherche (HimalCo project, ANR-12-CORP-0006, and LabEx EFL, ANR-10-LABX-0083Investissements d'Avenir) is gratefully acknowledged.

\section{References}

Barry, William. 1992. Comments on Browman and Goldstein: "Targetless schwa: an articulatory analysis." In Gerard J. Docherty \& Robert Ladd (eds.), Papers in laboratory phonology II: Gesture, segment, prosody, 65-67. Cambridge U.K.: Cambridge University Press.

Björverud, Susanna. 1998. A Grammar of Lalo. Lund: Lund University. Bradley, David. 1975. Nahsi and Proto-Burmese-Lolo. Linguistics of the Tibeto-Burman Area 2(1). 93-150. 
Bradley, David. 1989. Nasals and nasality in Loloish. In David Bradley, Eugénie J.A. Henderson \& Martine Mazaudon (eds.), Prosodic Analysis and Asian Linguistics: to honour R.K. Sprigg, 143-155. Canberra: Pacific Linguistics C-104.

Browman, Catherine P. \& Louis Goldstein. 1992. “Targetless” schwa: an articulatory analysis. In Gerard J. Docherty \& Robert Ladd (eds.), Papers in laboratory phonology II: Gesture, segment, prosody, 26-56. Cambridge U.K.: Cambridge University Press.

Brunelle, Marc \& Pittayawat Pittayaporn. 2012. Phonologically-constrained change: the role of the foot in monosyllabization and rhythmic shifts in Mainland Southeast Asia. Diachronica 29(4). 411-433.

Clarke, Constance M. \& Merrill F. Garrett. 2004. Rapid adaptation to foreign-accented English. Journal of the Acoustical Society of America 116(6). 3647-3658.

Fāng Guóyú 方国瑜 \& Hé Zhìwǔ 和志武. 1995. Nàxī Xiàngxíng Wénzìpǔ 纳西象形文字谱 $[A$ dictionary of Naxi pictographic characters]. Kūnmíng 昆明: Yúnnán rénmín chūbănshè 云南 人民出版社.

Fant, Gunnar. 1960. Acoustic theory of speech production, with calculations based on X-ray studies of Russian articulations. The Hague/ Paris: Mouton.

Fù Màojì 傅禁绩. 1981. Nàxĩzú túhuà wénzì “Báibiānfú qǔjīng shū” yánjiü 纳西族图画文字“白蝙 蝠取经书”研究 [A study of a Naxi pictographic manuscript, “White Bat's Search for Sacred Books"]. (Computational Analyses of Asian and African Languages Monograph Series, No. 6). Tokyo: CAAAL.

Gendrot, Cédric. n.d. ANALYSE1 (PRAAT script). Computer programme retrieved in May 2014 from http://gendrot.ilpga.fr/scripts.htm

Haudricourt, André-Georges. 1940. Méthode pour obtenir des lois concrètes en linguistique générale. Bulletin de la Société de Linguistique de Paris 41(1). 70-74.

Haudricourt, André-Georges. 1961. Bipartition et tripartition des systèmes de tons dans quelques langues d'Extrême-Orient. Bulletin de la Société de Linguistique de Paris 56(1). 163-80.

Haudricourt, André-Georges. 1972. Two-way and three-way splitting of tonal systems in some Far Eastern languages (Translated by Christopher Court). In Jimmy G. Harris \& Richard B. Noss (eds.), Tai phonetics and phonology, 58-86. Bangkok: Central Institute of English Language, Mahidol University.

Hé Jírén 和即仁 \& Jiāng Zhúyí 姜竹仪. 1985. Nàxīyǔ jiănzhì 纳西语简志 [A Brief Description of the Naxi Language]. Běijīng 北京: Mínzú chūbǎnshè 民族出版社.

Hé Kāixiáng 和开祥, Hé Lìmín 和力民, Xí Yùhuá 习煜华, Hé Yúnzhāng 和云章, Hé Shìchéng 和 士诚, Hé Jíguì 和即贵 \& Hé Qìngyuán 和庆元. 1989. Nàxī Dōngbā gǔjí yìzhù 纳西东巴古 籍译注（三）. [An annotated translation of Naxi Dongba classical texts], volume 3.

Yúnnánshěng shăoshù mínzú gǔjí zhěnglǐ chūbăn guīhuá bàngōngshì (Zhōngguó shăoshùmínzú gǔjí Yúnnánshěng shăoshù mínzú gǔjí yìcóng ) 云南省少数民族古籍整理出 版规划办公室 (中国少数民族古籍云南省少数民族古籍译丛). Kūnmíng 昆明: Yúnnán mínzú chūbǎnshè 云南民族出版社. 
Henrich, Nathalie, Christophe d'Alessandro, Michèle Castellengo \& Boris Doval. 2004. On the use of the derivative of electroglottographic signals for characterization of nonpathological phonation. Journal of the Acoustical Society of America 115(3). 1321-1332.

Huáng Bùfán 黄布凡. 2009. Mùlǐ Shuǐtiánhuà gàikuàng 木里水田话概况 [A survey of Muli Shuitian]. Hànzàngyǔ xuébào 汉藏语学报 [Journal of Sino-Tibetan Linguistics] 3. 30-55.

Hughes, Arthur, Peter Trudgill \& Dominic Watt. 2013. English accents and dialects. Fifth edition. Oxford: Routledge.

International Phonetic Association. 1949. The principles of the International Phonetic Association. Reprinted 1963. London: International Phonetic Association.

Jacques, Guillaume. 2004. Phonologie et morphologie du japhug (rGyalrong). Paris: Université Paris VII, UFR de Sciences du langage.

Jacques, Guillaume \& Alexis Michaud. 2011. Approaching the historical phonology of three highly eroded Sino-Tibetan languages: Naxi, Na and Laze. Diachronica 28(4). 468-498.

Janse, Esther \& Patti Adank. 2012. Predicting foreign-accent adaptation in older adults. Quarterly Journal of Experimental Psychology 65(8). 1563-1585.

Kirby, James. 2011. Vietnamese (Hanoi Vietnamese). Journal of the International Phonetic Association 41(3). 381-392.

Labov, William. 1994. Principles of linguistic change. Internal factors. (Language in Society 20). Oxford: Basil Blackwell.

Labov, William. 2001. Principles of linguistic change. Social factors. (Language in Society 29). Oxford: Basil Blackwell.

Labov, William. 2010. Principles of linguistic change. Volume 3: Cognitive and cultural factors. (Language in Society 39). Oxford, UK \& Malden, MA, USA: Wiley-Blackwell.

Lidz, Liberty. 2010. A descriptive grammar of Yongning Na (Mosuo). Austin: University of Texas, Department of linguistics. https://repositories.lib.utexas.edu/bitstream/handle/2152/ETD-UT2010-12-2643/LIDZ-DISSERTATION.pdf.

Li Lin-ts'an 李霖灿, Chang K’un 张琨 \& Ho Ts'ai 和才. 1953. Máxiē Xiàngxíngwénzì Zìdiăn 么些 象形文字字典 [A dictionary of Maxie pictographs]. Hong Kong: Shuōwén shè 说文社. Reprinted in 2001 by Yunnan Minzu Chubanshe under the title A Dictionary of Naxi pictographs (纳西象形标音文字字典).

Lǐ Zǐhè 李子鹤. 2012. Băoshān Nàxīyǔ yīnxì yánjiū 宝山纳西语音系研究 [Phonemic research about Baoshan Naxi]. Chámă gǔdào yánjiū jíkān 茶马古道研究集刊 2. 166-181.

Lǐ Zǐhè 李子鹤. 2013. Yuánshǐ Nàxīyǔ jíqí lìshǐ dìwèi yánjiū 原始纳西语及其历史地位研究 [Proto-Naish and its Genetic Position]. Běijīng dàxué bóshì xuéwèi lùnwén 北京大学博士学 位论文 (Beijing University Ph.D. dissertation).

Lǐ Zǐhè 李子鹤. 2014. Nàxī yǔyán yánjiū huígù — _ jiānlùn yǔyán zài wénhuà yánjiū zhōng de jīchǔ dìwèi 纳西语言研究回顾——兼论语言在文化研究中的基础地位 [A review of Naxi language studies, with a discussion of the fundamental role of cultural studies for linguistic research]. Chámă gǔdào yánjiū jikiann 茶马古道研究期刊 4.

Li, Zihe (李子鹤). 2014. The origin and evolution of retroflex finals in Naish languages. Journal of Chinese Linguistics 42(2). 309-329. 
Maeda, Shinji. 1996. Phonemes as concatenable units: VCV synthesis using a vocal-tract synthesizer. In A. Simpson \& M. Patzod (eds.), Sound patterns of connected speech: Description, models and explanation, 127-232. Kiel: Arbeitsberichte des Instituts für Phonetik und digitale Sprachverarbeitung 31.

Mazaudon, Martine. 1985. Review of: Anna Maria Hari, An investigation of the tones of Lhasa Tibetan. Linguistics of the Tibeto-Burman Area 8(1). 91-99.

Mazaudon, Martine \& Boyd Michailovsky. 1979. Naxi [Nahi]-English vocabulary.

Mazaudon, Martine \& Boyd Michailovsky. 2007. La phonologie panchronique aujourd'hui: quelques repères. In Jocelyne Fernandez-Vest (ed.), Combats pour les langues du monde: hommage à Claude Hagège, 351-362. Paris: L'Harmattan.

Michailovsky, Boyd, Martine Mazaudon, Alexis Michaud, Séverine Guillaume, Alexandre François \& Evangelia Adamou. 2014. Documenting and researching endangered languages: the Pangloss Collection. Language Documentation and Conservation 8. 119-135.

Michaud, Alexis. 2005. Prosodie de langues à tons (naxi et vietnamien), prosodie de l'anglais : éclairages croisés. Paris: Université Paris 3-Sorbonne Nouvelle, département de Sciences du langage.

Michaud, Alexis. 2006a. Three extreme cases of neutralisation: nasality, retroflexion and liprounding in Naxi. Cahiers de linguistique - Asie Orientale 35(1). 23-55.

Michaud, Alexis. 2006b. Tonal reassociation and rising tonal contours in Naxi. Linguistics of the Tibeto-Burman Area 29(1). 61-94.

Michaud, Alexis. 2008. Phonemic and tonal analysis of Yongning Na. Cahiers de linguistique - Asie Orientale 37(2). 159-196.

Michaud, Alexis. 2012. Monosyllabicization: patterns of evolution in Asian languages. In Nicole Nau, Thomas Stolz \& Cornelia Stroh (eds.), Monosyllables: from phonology to typology, 115-130. Berlin: Akademie Verlag. http:/halshs.archives-ouvertes.fr/halshs-00436432/.

Michaud, Alexis. 2013a. Review of: Pinson, Thomas M. 2012. A Naxi-Chinese-English Dictionary (Naqxi-Habaq-Yiyu Ceeqdiail / 纳西汉英词典). Linguistics of the Tibeto-Burman Area 36(2). 129-137.

Michaud, Alexis. 2013b. Studying level-tone systems in Asia: the case of the Naish languages. Proceedings of International Conference on Phonetics of the Languages in China (ICPLC2013), 1-6. Hong Kong.

Michaud, Alexis, He Limin \& Zhong Yaoping. Forthcoming. Naxi (Naish). In Rint Sybesma, Wolfgang Behr, Zev Handel \& C.T. James Huang (eds.), Encyclopedia of Chinese Language and Linguistics. Leiden: Brill.

Michaud, Alexis \& He Xueguang. 2007. Reassociated tones and coalescent syllables in Naxi (TibetoBurman). Journal of the International Phonetic Association 37(3). 237-255.

Michaud, Alexis \& Guillaume Jacques. 2012. The phonology of Laze: phonemic analysis, syllabic inventory, and a short word list. Yuyanxue Luncong 语言学论从 45. 196-230.

Michaud, Alexis, Guillaume Jacques \& Robert L. Rankin. 2012. Historical transfer of nasality between consonantal onset and vowel: from C to V or from V to C? Diachronica 29(2). 201230. 
Michaud, Alexis \& Xú Jìróng 徐继荣. 2012. Xiānggélîlā xiàn Cìēndīng cūn nàxīyǔ yīnxì yánjiū 香 格里拉县次恩丁村纳西语音系研究 [Research about the phonemic system of the Naxi dialect of Ciending village, Shangri-la prefecture]. Chámăgǔdào yánjiū jikān 茶马古道研究 集刊 2. 139-165.

Niebuhr, Oliver \& Alexis Michaud. 2015. Speech data acquisition: the underestimated challenge. KALIPHO - Kieler Arbeiten zur Linguistik und Phonetik 3. 1-42.

Pinson, Thomas M. 2012. A Naxi-Chinese-English Dictionary (Naqxi-Habaq-Yiyu Ceeqdiai /纳西 汉英词典). Kunming: Yunnan Minorities Publishing House (云南民族出版社).

Sagart, Laurent \& Xu Shixuan. 2001. History through loanwords: the loan correspondences between Hani and Chinese. Cahiers de linguistique - Asie Orientale 30(1). 3-54.

Vaissière, Jacqueline. 2007. Area functions and articulatory modeling as a tool for investigating the articulatory, acoustic and perceptual properties of the contrast between the sounds in a language. In Patrice Speeter Beddor, Maria Josep Solé \& Manjari Ohala (eds.), Experimental Approaches to Phonology, 54-72. Oxford: Oxford University Press.

Vaissière, Jacqueline. 2011a. On the acoustic and perceptual characterization of reference vowels in a cross-language perspective. Proceedings of ICPhS XVII. Hong Kong.

Vaissière, Jacqueline. 2011b. Proposals for a representation of sounds based on their main acousticoperceptual properties. In Elizabeth Hume, John Goldsmith \& W. Leo Wetzels (eds.), Tones and Features, 306-330. Berlin: De Gruyter Mouton.

Watson, Ian. 2002. Convergence in the brain; the leakiness of bilinguals' sound systems. In Mari Jones \& Edith Esch (eds.), Language change: The interplay of internal, external and extralinguistic factors, 243-266. (Contributions to the Sociology of Language 86). Mouton de Gruyter.

Wells, John C. 2001. IPA transcription systems for English. PG Bulletin: Bulletin of teachers of English phonetics in Chile and abroad 9 . Available: http://www.phon.ucl.ac.uk/home/wells/ipa-english-uni.htm

Yáng Huàndiăn 杨焕典. 1984. Lùn Nàxīyǔ yīnwèi xìtǒng 论纳西语音位系统 [About the phonemic system of Naxi]. Computational Analyses of Asian and African Languages Monograph series 22. 131-146.

Zēng Xiăopéng 曾小鹏. 2011. Éyà Tuōdìcūn Nàxī yǔyán wénzì yánjiū 俄亚托地村纳西语言文字 研究 [Research about the language and writing system of Eya Naxi (Tuodi village)]. Chóngqìng 重庆: Xīnán dàxué bóshì xuéwèi lùnwén 西南大学博士学位论文 (Chongqing University Ph.D. dissertation). 
Appendix A: Words illustrating the opposition between the two rhotic rhymes $/ \mathrm{r} /$ and $/ \mathrm{ur} /$ in Pianding Naxi This list is arranged by alphabetic order of IPA forms. Words are presented in phonemic notation. PS $=$ part of speech. The mention $\mathrm{CH}$ signals Chinese borrowings.

\begin{tabular}{|c|c|c|c|}
\hline IPA & PS & Chinese gloss & English gloss \\
\hline$æ\rfloor p^{\mathrm{h}} \gamma \mathrm{f}$ & $\mathrm{N}$ & 公鸡 & rooster \\
\hline$æ\rfloor p^{\mathrm{h}} \gamma^{\prime-1 t u r-1 l u r-1}$ & $\mathrm{~N}$ & 小公鸡 & cockerel \\
\hline brot & $\mathrm{N}$ & 客人 & guest, visitor \\
\hline bort & $\mathrm{N}$ & 酒席, 宴席 & marriage feast \\
\hline bru & $\mathrm{N}$ & 稗 & barnyard grass; millet \\
\hline bru & ADJ & 热闹的, 起劲的 & hilarious \\
\hline bru & $\mathrm{V}$ & 散架，解体 & to fall apart; to scatter, to disperse \\
\hline bru & $\mathrm{V}$ & 冒（水） & to gush, to leak \\
\hline brı-br-1] & $\mathrm{N}$ & 小腿或手臂上的肌肉 & shank \\
\hline br-tbr-17 & $\mathrm{N}$ & 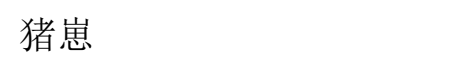 & piglet \\
\hline britdry & $\mathrm{N}$ & 白地 & Baidi (place name) \\
\hline$b x-11 x-1$ & ADJ & 恶心 & nauseous, disgusting \\
\hline$b x^{-1 n} x^{-1}$ & ADJ & 柔软的 & soft \\
\hline bułciłz!̣ -1 - & $\mathrm{N}$ & 虫名 & insect $\mathrm{sp}$. \\
\hline bu」meł-nur-t $\left.{ }^{\mathrm{h}} \mathrm{i}\right\rfloor$ & $\mathrm{N}$ & 蒲公英 & dandelion \\
\hline buJ-ts sh $^{\mathrm{h}}-\mathrm{s}$-su-1 & $\mathrm{N}$ & 琵琶肉 & lard, fat meat of pig \\
\hline $\operatorname{crl}$ & $\mathrm{V}$ & 脱臼 & to disjoint \\
\hline$c c^{\top}$ & $\mathrm{V}$ & 挖, 挖掘 & to dig \\
\hline$c c^{-1}$ & $\mathrm{~N}$ & 脖子 & neck \\
\hline$c c^{-1}$ & $\mathrm{~N}$ & 杯子 & little cup \\
\hline$c x^{\prime}$ & PREP & 比……, $\cdots \cdot \cdots$ 之上 & than; upward \\
\hline$c x^{\prime}$ & $\mathrm{V}$ & 用勺子舀 & to ladle, to bale out with a spoon \\
\hline$c x^{\prime}$ & $\mathrm{V}$ & 用木棍, 铁线等勾上来 & to pick with a hook \\
\hline $\operatorname{coc} 71 x-1$ & $\mathrm{~V}$ & 使劲儿翻找, 搜刮 & to rummage through; to plunder \\
\hline$\left.c x^{\prime}-1 x^{\prime}\right\rfloor$ & $\mathrm{N}$ & 秋千 & swing \\
\hline çr $71 \mathrm{o}\rfloor$ & $\mathrm{N}$ & 大理（地名） & Dali (place name) \\
\hline çּ-ngæ」 & $\mathrm{N}$ & 交叉的形状, 即 “ $\times ”$ & a "X" mark \\
\hline 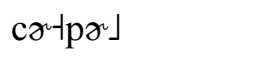 & $\mathrm{N}$ & 脖颈儿 & nape \\
\hline $\operatorname{cr} 7 t x-1$ & $\mathrm{~N}$ & $\begin{array}{l}\text { 有家畜的人家去山神树旁 } \\
\text { 野炊 }\end{array}$ & ritual to the spirit of cattle \\
\hline $\operatorname{cor} \mid \operatorname{ts} \gamma^{\prime} 7$ & $\mathrm{~N}$ & 脖子（气管） & trachea \\
\hline $\operatorname{cur}\urcorner$ & $\mathrm{V}$ & 射（水, 泥浆） & to send out, to sprinkle (water) \\
\hline$c^{\mathrm{h}} \gamma^{\mathrm{\gamma}}$ & ADJ & 烧焦的 & to scorch \\
\hline$c^{\mathrm{h}} \gamma^{\mathrm{t}}$ & $\mathrm{N}$ & 屎 & feces \\
\hline$c^{h} \gamma-1$ & $\mathrm{~V}$ & 断 & to break (a stick breaks) \\
\hline $\mathrm{c}^{\mathrm{h}} \gamma \dashv \mathrm{m} æ 1$ & $\mathrm{~N}$ & 最后一名, 倒数第一 & tail-ender, last in a set \\
\hline$c^{\mathrm{h}}$ ur-1 & ADV $\quad C H$ & 确实 & truly \\
\hline
\end{tabular}




\begin{tabular}{|c|c|c|c|}
\hline$d x-1$ & $\mathrm{~V}$ & 发芽（树木） & to sprout \\
\hline $\mathrm{d} \mathfrak{x}^{\prime}$ & $\mathrm{N}$ & 骡 & mule \\
\hline durt & $\mathrm{N}$ & 放粮食, 干果的竹席 & $\begin{array}{l}\text { bamboo mat where one places } \\
\text { cereals, dried fruit }\end{array}$ \\
\hline dur & $\mathrm{N}$ & 泡沫 & foam \\
\hline dur & $\mathrm{V}$ & 蹂路 & to devastate \\
\hline dzox-17it & $\mathrm{N}$ & 鸟名 & bird sp. \\
\hline dz̧urddzurut & ADJ & 病态, 萎靡 & listless \\
\hline 27 & $\mathrm{CH}$ & 二 & two \\
\hline $\mathfrak{a}^{\mathrm{h}} \mathrm{w} \mathfrak{\rceil}$ & $\mathrm{N}$ & 锣 & gong \\
\hline$\partial 7 c^{h} \partial-1$ & $\mathrm{~N}$ & 小拇指 & little finger \\
\hline$\partial 7 c^{\mathrm{h}} \gamma-1$ & $\mathrm{~N}$ & 虫名 & insect sp. \\
\hline 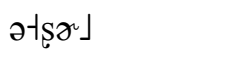 & $\mathrm{N}$ & 筷子 & chopsticks \\
\hline ołș & $\mathrm{N}$ & 文化（地名） & Wenhua (place name) \\
\hline 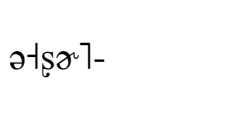 & PREF & 在时间名词前表示过去 & $\begin{array}{l}\text { expresses the past, in time } \\
\text { expressions }\end{array}$ \\
\hline 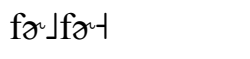 & ADJ & 形容风吹 & hissing (description of wind noise) \\
\hline fụ & $\mathrm{N}$ & 瘊子 & wart \\
\hline gụ Jnurt & $\mathrm{N}$ & 水冬瓜（植物名） & plant sp. \\
\hline hur-llurt & $\mathrm{ADJ}$ & 剃得很干净的 & neat and tidy (eg face after shaving) \\
\hline hultph $\gamma^{\mathrm{h}}$ & $\mathrm{N}$ & 粉条 ～～～～～～～～～ & bean noodles \\
\hline i $7 p \gamma^{\top} 7$ & $\mathrm{~V}$ & 吵醒人, 让人睡不好觉 & to wake sb. up by noise \\
\hline $\mathrm{j} \mathfrak{\mathrm { j }} \mathrm{t} \mathfrak{- 1}$ & $\mathrm{N}$ & 火柴 & matches \\
\hline kæ†-ş7-nił & $\mathrm{N}$ & 大前天 & three days ago \\
\hline $\mathrm{k} \gamma 7 \mathrm{r}-\mathrm{t}$ & $\mathrm{V}$ & 掏, 寻找, 翻寻 & to look for \\
\hline kr-llel-cr」 & $\mathrm{N}$ & 环，扣 & hook \\
\hline ki $11 i-t-k u r\urcorner l u r-$ & ADJ & 形容凹凸不平 & uneven \\
\hline ki-tit-ka -tar- & ONO & 叮叮当当 & sound of clatter, jingle \\
\hline kurtlunt & ADJ & 悲哀， 伤心 & sad, grieved \\
\hline $\mathrm{k}^{\mathrm{h}} \mathrm{i}-1 \mathrm{i}--\mathrm{k}^{\mathrm{h}} \partial-1 \mathrm{\partial}-1$ & ONO & 摇骰子的声音 & noise of shaking dice \\
\hline$\left.k^{h} u^{n}\right\urcorner l u n t$ & ADJ & 蜷曲 ～～～～～～～～～～ & to curl up; to hunch, to huddle up \\
\hline $\mathrm{k}^{\mathrm{h}} \mathrm{ur}-1 \mathrm{ur}-1$ & $\mathrm{~N}$ & 孔, 洞, 坑 & hole, cavity \\
\hline $\mathrm{k}^{\mathrm{h}} \mathrm{ur}+\mathrm{tur} \mathrm{r}$ & $\mathrm{N}$ & 口袋口打的结 & knot to close a bag \\
\hline $\left.\mathrm{k}^{\mathrm{h}} \mathrm{w}\right\lrcorner \mathrm{z} \partial \mathrm{\gamma}^{-1}$ & $\mathrm{~N}$ & 线, 针线 & thread \\
\hline $\mathrm{k}^{\mathrm{h}} v \mathbf{v} 7 \mathrm{tur} 7$ & $\mathrm{~N}$ & 傍晚 & toward evening, at nightfall \\
\hline la $\dashv$ pr $\rceil$ & $\mathrm{N}$ & 虎纹 & stripes, tiger stripes \\
\hline la $\left.\lrcorner p \gamma^{\top}\right\rceil$ & $\mathrm{N}$ & 戒指 & ring \\
\hline lałșa」zoł & $\mathrm{N}$ & 粮架的横梁 & $\begin{array}{l}\text { horizontal part of the rack for drying } \\
\text { grain }\end{array}$ \\
\hline la」-tşa & $\mathrm{N}$ & 手 & hand \\
\hline la」-ts $\left.{ }^{h} u ̛\right\urcorner$ & $\mathrm{N}$ & 火枪 & gun; firelock \\
\hline
\end{tabular}




\begin{tabular}{|c|c|c|c|}
\hline la」tsh $\left.\left.{ }^{\mathrm{h}} u ̛\right\urcorner n d v\right\rfloor$ & $\mathrm{N}$ & 拳 & fist \\
\hline 127 & $\mathrm{~V}$ & 量 & to measure \\
\hline $1 \not \gamma$ & $\mathrm{N}$ & 种子 & grain \\
\hline $\left.1 \partial^{\prime}\right\rfloor$ & $\mathrm{V}$ & 扬（谷物） & to winnow \\
\hline $\left.1 \gamma^{\prime}\right\rfloor$ & $\mathrm{V}$ & 喊, 叫唤 & to scream \\
\hline $\left.1 \gamma^{\lrcorner}\right\rfloor \mathrm{k}^{\mathrm{h}} \mathrm{a}-$ & $\mathrm{N}$ & 温泉 & warm springs \\
\hline leł-ndx」 & $\mathrm{N}$ & 回族 & Hui (ethnic group) \\
\hline l’’ 7 tse $\rfloor$ & $\mathrm{N}$ & 东西, 工具 & tool, thing, thingummy \\
\hline lurt & $\mathrm{V}$ & 渴求, 渴望 & to anticipate \\
\hline $\operatorname{lurt}$ & CLF & 口 & a mouthful of \\
\hline $\operatorname{lur} t$ & $\mathrm{~N}$ & 腮, 腮帮子 & cheek \\
\hline $\operatorname{lur}\rfloor$ & $\mathrm{N}$ & 轭 & yoke \\
\hline $\operatorname{lur}\rfloor$ & $\mathrm{V}$ & 比得过; 打得过; 能胜任 & to be able (to win), to be up to \\
\hline lurtbe」 & $\mathrm{N}$ & 嘴巴 & mouth and jaw \\
\hline $\operatorname{lur}-\mathrm{k}^{\mathrm{h}} \gamma 7$ & $\mathrm{~N}$ & 椽子 & rafter; beam \\
\hline$m x^{7}$ & $\mathrm{~V}$ & 闭 & to close \\
\hline $\mathrm{mj} \gamma\lrcorner-\mathrm{mbr}-1$ & $\mathrm{~N}$ & 眼泪 & tear \\
\hline $\left.\operatorname{mj} \gamma\rfloor \mathrm{ts}^{\mathrm{h}} \gamma \dashv-\mathrm{ka}\right\rfloor$ & $\mathrm{V}$ & 斜眼看人（极不礼貌地） & to look askance at \\
\hline mulnurtc $\left.\mathrm{c}^{\mathrm{h}} \mathrm{i}\right\rfloor$ & $\mathrm{N}$ & 菌名 & mushroom sp. \\
\hline mbrt & $\mathrm{N}$ & 槽（引水） & groove, trough (for water) \\
\hline $\mathrm{mbrt}$ & $\mathrm{N}$ & 化脓; 脓包 & pus \\
\hline $\mathrm{mbrt}$ & $\mathrm{V}$ & 搬（家） & to move house \\
\hline $\operatorname{mbr}\rfloor$ & $\mathrm{V}$ & 烧，焚 & to burn \\
\hline $\mathrm{mbr} 7$ & $\mathrm{~V}$ & $\begin{array}{l}\text { 失去平衡而尧翻（如坐长 } \\
\text { 登时） }\end{array}$ & to lose one's balance and fall over \\
\hline $\mathrm{mbr}\rfloor$ & $\mathrm{N}$ & 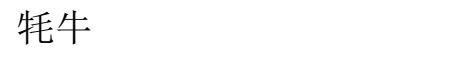 & yak \\
\hline$m b \gamma-1 x\urcorner$ & $\mathrm{N}$ & 苍蝇 & fly \\
\hline $\mathrm{mbr}-\mathrm{ts} \underline{1}\rceil$ & $\mathrm{N}$ & 蚊子 & mosquito \\
\hline 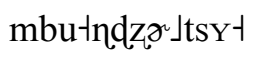 & $\mathrm{N}$ & 鸟名 & bird sp. \\
\hline 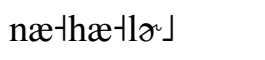 & ADJ & 恶心的 & sick, nauseous \\
\hline na」-lø $\urcorner$ & ADJ & 黑的, 黑色 & black \\
\hline nat-ndzą- & $\mathrm{N}$ & 油炸糯米饼 & fried glutinous rice cake \\
\hline næ 7 & $\mathrm{~V}$ & 压扁, 挤压 & to press; to flatten; to squeeze \\
\hline no $\lrcorner$ jurt 7 & $\mathrm{CH}$ & 农药 & pesticide \\
\hline nurt & ADJ & 糯, 粘稠 & sticky \\
\hline nurt & $\mathrm{V}$ & 醒, 知道 & to be awake \\
\hline nurt & $\mathrm{N}$ & 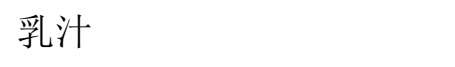 & milk (animals' milk) \\
\hline nur $\rfloor$ & $\mathrm{N}$ & 蛆（肉上的）, 蛙虫 & maggot \\
\hline nur?nurt & $\mathrm{V}$ & 纠缠, 打乱 & to tangle, to upset \\
\hline ni \ñ」 & $\mathrm{N}$ & 唢呐 & clarinet \\
\hline ndxt & $\mathrm{V}$ & 要, 应该 & to have to, to be necessary \\
\hline
\end{tabular}




\begin{tabular}{|c|c|c|c|}
\hline$n d x-1$ & $\mathrm{~V}$ & 得到, 轮到 & to be one's turn \\
\hline ndr」 & $\mathrm{N}$ & 肥料 & manure, excrement \\
\hline ndr」 & $\mathrm{N}$ & 浑浊 & muddy, turbid \\
\hline ndr」 & $\mathrm{V}$ & 涉水（过河） & to go through, to wade across \\
\hline ndurt & $\mathrm{V}$ & 犯错 & to make a mistake \\
\hline ndurt & $\mathrm{N}$ & 潭, 池 & pond \\
\hline ndurt & $\mathrm{V}$ & 蛰 & to sting (bee) \\
\hline ndrt & ADJ & 短, 短的 & short \\
\hline ndzatcort & ADJ & 瘦骨如柴的 & skinny, thin (person) \\
\hline ఇdzurt-nụ」 & $\mathrm{V}$ & 膻味, 腥味; 有膻味 & gamy/fishy smell \\
\hline ndzurt & $\mathrm{N}$ & 露水 & dew \\
\hline ndzurt & $\mathrm{N}$ & 霜 & frost \\
\hline ndzurt & $\mathrm{V}$ & 游泳, 漂浮 & to swim \\
\hline ndzurut & ADJ & 湿 & moist, wet, damp, humid \\
\hline ndzur」 & $\mathrm{V}$ & 溶化 & to melt \\
\hline jrาmbr」 & $\mathrm{N}$ & 蝗虫 & locust \\
\hline niาm $\gamma^{\prime}$ & $\mathrm{N}$ & 鼻子 & nose \\
\hline jiłtur-1ur」 & $\mathrm{N}$ & 牛鼻棍 & a cow's nasal ring \\
\hline njot & ADJ & 䔍儿的 & listless \\
\hline nfact & $\mathrm{ADJ}$ & 跛 & cripple, lame person \\
\hline$\left.n_{f} \gamma^{\prime}\right\rfloor$ & $\mathrm{N}$ & 树脂 & resin \\
\hline $\mathrm{nfa}\rfloor$ & $\mathrm{V}$ & 胜任, 比得过 & to be qualified, to tally with \\
\hline $\left.\mathrm{n}_{\mathrm{f}} \mathrm{x}\right\rfloor$ & $\mathrm{V}$ & 炼油（炒菜） & to heat (oil) \\
\hline $\mathrm{nfr} 7$ & $\mathrm{~V}$ & 烤, 多 & $\begin{array}{l}\text { to roast, to grill; to warm oneself at } \\
\text { a fire; to bask in the sun }\end{array}$ \\
\hline$\left.n_{f y} \dashv p^{h} \gamma^{\prime}\right\rfloor$ & $\mathrm{N}$ & 芜菁 & turnip, wild cabbage \\
\hline pr-17 & ONO & 放屁的声音 & sound of farting \\
\hline pr 7 & $\mathrm{~V}$ & 梳 & to comb; comb \\
\hline pr 7 & $\mathrm{~V}$ & 写 & to write \\
\hline pr」 & CLF & 泡（屎） & clf for excrements \\
\hline pr」 & $\mathrm{V}$ & 拔 & to pull out (weeds), to weed \\
\hline prtlot & $\mathrm{N}$ & 小盒子 & caddy \\
\hline pr $\left.\urcorner p \gamma^{\circ}\right\rceil$ & $\mathrm{N}$ & 汽车 & car (child word) \\
\hline prottat & ONO & 水烧开的声音 & sound of boiling water \\
\hline prits $1-1$ & $\mathrm{~N}$ & 篦子 & fine comb (used to comb out lice) \\
\hline $\mathrm{p}^{\mathrm{h}} \gamma^{\mathrm{u}}$ & ADJ & 白 & white \\
\hline pur?lurt & $\mathrm{N}$ & 嗉; 胸脯 & crop (of a chicken); chest \\
\hline şr & $\mathrm{N}$ & 污垢, 汗渍 & dirt, filth \\
\hline ş' & $\mathrm{V}$ & 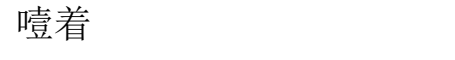 & to choke \\
\hline şa & $\mathrm{V}$ & 拧（衣服），赎回，夺回 & to twist, to wring; to ransom \\
\hline şว 7 & $\mathrm{~V}$ & 挪动，拖动 & to move, to shift \\
\hline
\end{tabular}




\begin{tabular}{|c|c|c|c|}
\hline şat & $\mathrm{N}$ & 事，事情 & work, occupation, task, event \\
\hline sout & $\mathrm{N}$ & 七 & seven \\
\hline ş山 & ADJ & 长的 & long \\
\hline şu & $\mathrm{V}$ & 牵 (手, 牛), 拉着 & to lead along (by hand, halter...) \\
\hline sal & $\mathrm{V}$ & 搅，拌 & to stir \\
\hline 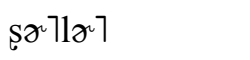 & $\mathrm{V}$ & 拧 & to twist, to wring \\
\hline $\sin \urcorner$ & ADJ & 满的 & full \\
\hline surt & $\mathrm{N}$ & 印, 痕, 痕迹; 明显的 & (foot...)print, trace \\
\hline șurtlurt & $\mathrm{N}$ & 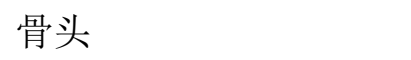 & bone \\
\hline şur'şurt & $\mathrm{V}$ & 佐食 & snack \\
\hline ta」mbr-1lat & $\mathrm{N}$ & 双面鼓 & double-faced drum \\
\hline ta-p $\left.\gamma^{\top}\right\rceil$ & $\mathrm{N}$ & 扁担 & carrying/shoulder pole \\
\hline tałprา & ADJ & 癔的 & flat, shrivelled, shrunken \\
\hline tr 7 & $\mathrm{~V}$ & 关（门，羊） & $\begin{array}{l}\text { to lock up (animals), to close (a } \\
\text { door) }\end{array}$ \\
\hline $\operatorname{tr} 7 \operatorname{tr}\urcorner$ & ONO & 发电报的声音 & $\begin{array}{l}\text { sound of typing on a telegram } \\
\text { machine }\end{array}$ \\
\hline $\operatorname{tur} 7$ & $\mathrm{~V}$ & 纺, 织 & to weave \\
\hline $\operatorname{tur} 7$ & CLF & 棵 & clf for trees \\
\hline $\operatorname{tur} 7$ & $\mathrm{~V}$ & 能胜任, 有能力 & to be able to \\
\hline turt & $\mathrm{V}$ & 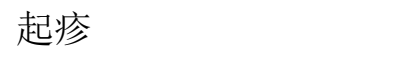 & to have a rash \\
\hline tur & $\mathrm{V}$ & 强行闯入 & to force one's way in \\
\hline $\operatorname{tur}\rfloor$ & $\mathrm{N}$ & 砧板, 木桩, 木墩 & anvil, cutting-board \\
\hline turiturt & $\mathrm{V}$ & 包装，包裹 & to wrap, to pack, to coil (fabric) \\
\hline turilurt & $\mathrm{V}$ & 打结（绳子） & to tie a knot \\
\hline tur」-şu- & $\mathrm{N}$ & 人断气时没有人在身边 & to die without anyone at one's side \\
\hline tur?lurt & $\mathrm{N}$ & 土块，团 & clod of earth \\
\hline $\mathrm{t}^{\mathrm{h}} \mathrm{\gamma} \mathrm{T}$ & $\mathrm{V}$ & 咬，叮 & to bite; to sting, to gnaw, to nibble \\
\hline $\left.\mathrm{t}^{\mathrm{h}} \mathrm{r}\right\rfloor$ & $\mathrm{N}$ & 裙，裙子 & skirt \\
\hline $\mathrm{t}^{\mathrm{h}} \boldsymbol{r}^{\mathrm{c}} \mathrm{kku}-\mathrm{t}$ & $\mathrm{CH}$ & 调美 & small spoon, used for salt \\
\hline $\mathrm{t}^{\mathrm{h}} \mathrm{x}_{\mathrm{Z}} \mathrm{zwa}$ & $\mathrm{N}$ & 驴 & donkey, ass \\
\hline $\left.\mathrm{t}^{\mathrm{h}} \mathrm{ur}\right\urcorner \mathrm{t}^{\mathrm{h}} \mathrm{urt}$ & $\mathrm{V}$ & 卷, 包裹 & to roll, to coil (fabric) \\
\hline $\left.\operatorname{ts}^{\mathrm{h}} \prod_{1}\right\rfloor \mathrm{cur}^{\mathrm{r}} \mathrm{T}$ & ADJ & 细细的 & extremely thin \\
\hline $\operatorname{ts} \gamma 7$ & $\mathrm{~V}$ & 淹, 淹没; 涝 & to flood, to inundate \\
\hline $\operatorname{ts} \gamma^{\prime} 7$ & $\mathrm{~N}$ & 关节 & $\begin{array}{l}\text { ankle, joint (between the foot and } \\
\text { the leg) }\end{array}$ \\
\hline $\operatorname{ts} \gamma^{2} 7$ & $\mathrm{~V}$ & 腌制 & to pickle/salt (food) \\
\hline $\operatorname{ts} x-1$ & $\mathrm{~N}$ & 瘊子 & wart \\
\hline tso-t & $\mathrm{N}$ & 植物名 & plant sp. \\
\hline tso & $\mathrm{V}$ & 指使, 指 & to command, to give orders to \\
\hline 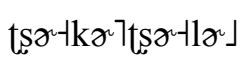 & $\mathrm{N}$ & 鸟名 & bird sp. \\
\hline
\end{tabular}




\begin{tabular}{|c|c|c|c|}
\hline ts $\left.x^{\prime}\right\urcorner 1 \partial-1$ & $\mathrm{~N}$ & 短小的木头 & small piece of wood \\
\hline tşa & $\mathrm{N}$ & 汁罗（地名） & Jiluo (place name) \\
\hline tşat-muך & $\mathrm{N}$ & 菌名 & mushroom sp. \\
\hline 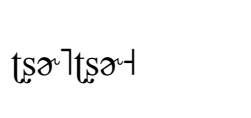 & $\mathrm{N}$ & $\begin{array}{l}\text { 推测的大概位置（时间和 } \\
\text { 空间） }\end{array}$ & $\begin{array}{l}\text { conjectured position (in time or } \\
\text { space) }\end{array}$ \\
\hline $\operatorname{ts}^{\mathrm{h}} \gamma^{\mathrm{\gamma}} \mathrm{T}$ & $\mathrm{N}$ & 代, 辈 & generation \\
\hline$t s^{\mathrm{h}} \gamma-\mathrm{t}$ & $\mathrm{V}$ & 腐烂 & to rot \\
\hline$t s^{\mathrm{h}} \gamma-\mathrm{t}$ & $\mathrm{V}$ & 洗 & to wash (clothes, oneself...) \\
\hline $\operatorname{ts}^{\mathrm{h}} \gamma^{\mathrm{j}}$ & ADJ & 高兴, 愉悦 & pleased, happy, delighted \\
\hline $\left.\operatorname{tss}^{\mathrm{h}} \gamma^{\mathrm{c}}-\mathrm{j} \mathrm{j}\right\rfloor$ & $\mathrm{N}$ & 雨季在石崖上滴下的水 & $\begin{array}{l}\text { water that drips from cliffs during } \\
\text { the rainy season }\end{array}$ \\
\hline $\mathrm{ts}^{\mathrm{h}} \mathrm{\gamma}^{\mathrm{J}} \mathrm{-j}_{\mathrm{j}} \mathrm{J}$ & $\mathrm{N}$ & 精液 & sperm \\
\hline$\left.t^{h} \gamma-k^{h} u\right\rceil$ & $\mathrm{V}$ & 淬火 & to quench \\
\hline$t s^{h} \gamma-1 w 1$ & $\mathrm{~N}$ & 药 & medicine \\
\hline $\left.\operatorname{ts}^{h} u ̛\right\urcorner$ & $\mathrm{N}$ & 肺 & lung \\
\hline $\operatorname{ts}^{\mathrm{h}} u \mathrm{r}^{\mathrm{r}}$ & $\mathrm{V}$ & 握 （握刀把） & to grasp (e.g. a sword hilt) \\
\hline$t^{\mathrm{h}}{ }^{\mathrm{h}} \mathrm{urt}$ & $\mathrm{V}$ & 兑，掺 & to add water, to pour extra water \\
\hline$\left.t^{h}{ }^{h} u r\right\urcorner-k^{h} u r-1$ & $\mathrm{~N}$ & 喉咙 & throat \\
\hline ts ${ }^{\mathrm{h}} \mathrm{ur}-\mathrm{me} \mathrm{t}^{-1}$ & $\mathrm{~N}$ & 媳妇 & wife; son's wife \\
\hline$t s^{\mathrm{h}} u r-t^{\mathrm{h}} v-1$ & ADJ & 守寡的 & who remains a widow \\
\hline $\operatorname{ts} x-1$ & $\mathrm{~N}$ & 植物名 & plant sp. \\
\hline tsur $\urcorner$ & $\mathrm{V}$ & 吓, 吓人 & to scare, to threaten \\
\hline tsurt & $\mathrm{V}$ & 咳, 咳嗽 & to cough \\
\hline tsur $\rfloor$ & $\mathrm{V}$ & 捅（用刀），浸（水） & to poke (with a knife); to soak \\
\hline var $7 v a r t$ & $\mathrm{~V}$ & 拖动, 移动 (吃力地) & to cause to move (forcefully) \\
\hline wæ-t-şך 7 & ADJ & 歪的 & askew, crooked \\
\hline 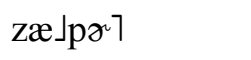 & $\mathrm{N}$ & 酒窝 & dimple \\
\hline 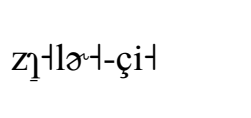 & $\mathrm{N}$ & $\begin{array}{l}\text { 纳西族舞蹈 zeJmet中的女 } \\
\text { 声部 }\end{array}$ & $\begin{array}{l}\text { the female role in the } / \mathrm{ze}\rfloor \mathrm{me}-1 / \\
\text { singing style }\end{array}$ \\
\hline$z\rceil-1-m u\rceil n d z u r\rfloor$ & $\mathrm{N}$ & 菌名 & mushroom sp. \\
\hline$z \ngtr-1$ & ADJ & 害怕 & to be scared, to be afraid \\
\hline$z \ngtr-z \partial-1$ & $\mathrm{~V}$ & 挪动，移动 & to remove \\
\hline$\left.z x^{\prime}\right\rfloor$ & $\mathrm{V}$ & 响, 发出响声 & to make noise \\
\hline$\left.z x^{\prime}\right\rfloor$ & $\mathrm{N}$ & 柱子 & pillar \\
\hline zuurt & $\mathrm{V}$ & 不出声, 装作没听见 & silent, pretending not to hear \\
\hline z̧山ل」 & $\mathrm{V}$ & 压, 挤, 过分的玩弄 & $\begin{array}{l}\text { to rub, to knead (e.g. rub one's } \\
\text { hands) }\end{array}$ \\
\hline zurt-dy」 & $\mathrm{N}$ & 指山下低海拔地区 & $\begin{array}{l}\text { low-altitude area at the foot of } \\
\text { mountains }\end{array}$ \\
\hline$\left.z u r t k^{h} a\right\rfloor$ & $\mathrm{N}$ & 阮卡（地名） & Ruanka (place name) \\
\hline
\end{tabular}




\section{Appendix B: Words illustrating the syllabic inventory of Pianding Naxi}

This list is arranged by alphabetic order of IPA forms. Words are presented in phonemic notation. PS = part of speech. The mention $\mathrm{CH}$ signals Chinese borrowings.

\begin{tabular}{|c|c|c|c|c|}
\hline IPA & PS & & Chinese gloss & English gloss \\
\hline $\mathrm{a}\rfloor$ & $\mathrm{V}$ & & 吃草（牛） & to graze \\
\hline$æ-1$ & $\mathrm{~N}$ & & 铜 & brass, copper, bronze \\
\hline $\mathrm{ba}\rfloor$ & $\mathrm{N}$ & & 花 & flower \\
\hline bæ」 & $\mathrm{N}$ & $\mathrm{CH}$ & 牌 & poker; mahjong \\
\hline brt & $\mathrm{N}$ & & 客人 & guest, visitor \\
\hline bet & $\mathrm{V}$ & & 做, 工作 & to do, to work \\
\hline brt & $\mathrm{N}$ & & 普米族 & Pumi/Prinmi (ethnic group) \\
\hline bi」 & ADJ & & 简单, 容易 & easy \\
\hline bjrt & $\mathrm{N}$ & & 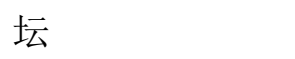 & jar \\
\hline bu」 & ADJ & & 多 & many, much \\
\hline bu」 & $\mathrm{N}$ & & 猪 & pig \\
\hline bụt & $\mathrm{N}$ & & 锅 & pot \\
\hline by & $\mathrm{N}$ & & 面粉, 粉末 & powder; flour \\
\hline $\mathrm{cat}$ & $\mathrm{V}$ & $\mathrm{CH}$ & 加 & to add \\
\hline cæłæ」 & $\mathrm{N}$ & & 酸菜 & pickles \\
\hline$c^{2} 7$ & $\mathrm{~V}$ & & 脱臼 & to disjoint \\
\hline ce-17 & $\mathrm{N}$ & $\mathrm{CH}$ & 级 & class \\
\hline $\mathrm{cr} 7$ & $\mathrm{~V}$ & & 煮 & to boil \\
\hline ci 7 & $\mathrm{~N}$ & & 口水, 唾液 & saliva \\
\hline $\operatorname{cur}\urcorner$ & $\mathrm{V}$ & & 射（水） & to send out (water) \\
\hline cwæ- & V & $\mathrm{CH}$ & 卷 & to roll \\
\hline cwet & $\mathrm{N}$ & $\mathrm{CH}$ & 军 & troops, amy \\
\hline $\mathrm{cY} 7$ & ADJ & & 麻的，酸痛 & numb \\
\hline$c ̧ a\rceil$ & $\mathrm{V}$ & & 干, 做; 吃, 喝 & to do; to eat \\
\hline çæ- & $\mathrm{N}$ & $\mathrm{CH}$ & 乡 & county \\
\hline çe-17t $t^{\mathrm{h}}$ je-17 & $\mathrm{N}$ & $\mathrm{CH}$ & 吸铁 & magnet \\
\hline çજ 7 & $\mathrm{~V}$ & & 涂抹 & to daub \\
\hline çi $\rceil$ & $\mathrm{N}$ & & 舌, 舌头 & tongue \\
\hline çurtlurt & ADJ & & 光滑的 & smooth \\
\hline çwæ」 & ADJ & & 厉害 & fierce \\
\hline çwe 1 & $\mathrm{~V}$ & $\mathrm{CH}$ & 训 & to train \\
\hline çY $\rceil$ & $\mathrm{N}$ & & 柏 & cypress \\
\hline$c^{h} a-$ & $\mathrm{V}$ & $\mathrm{CH}$ & 敲 & to knock \\
\hline$c^{\mathrm{h}} \mathfrak{\rceil}$ & $\mathrm{V}$ & $\mathrm{CH}$ & 欠 & to own \\
\hline$c^{\mathrm{h}} \gamma^{\mathrm{l}}$ & ADJ & & 烧焦的 & scorching \\
\hline$\left.c^{\mathrm{h}} \gamma\right\rceil$ & $\mathrm{V}$ & & 贴 & to glue (two objects together) \\
\hline
\end{tabular}




\begin{tabular}{|c|c|c|c|c|}
\hline$\left.c^{h} \mathrm{i}\right\rceil$ & $\mathrm{N}$ & & 冷, 凉 & cold (weather, water) \\
\hline$c^{\mathrm{h}} \mathrm{ur}-1$ șu-17 & $\mathrm{ADV}$ & $\mathrm{CH}$ & 确实 & true \\
\hline$c^{\mathrm{h}} w æ-1$ & $\mathrm{~N}$ & $\mathrm{CH}$ & 圈 & pen, sty \\
\hline $\left.\mathrm{c}^{\mathrm{h}} \mathrm{we}\right\rfloor$ & $\mathrm{N}$ & $\mathrm{CH}$ & 裙 & skirt \\
\hline$\left.c^{\text {h }} \mathrm{Y}\right\rceil$ & $\mathrm{V}$ & & 削 & to chop \\
\hline $\mathrm{da}\rfloor$ & $\mathrm{V}$ & & 飞, 飘 & to soar; to float \\
\hline $\mathrm{d} \rightsquigarrow \dashv l \underline{1}\rfloor$ & $\mathrm{N}$ & & 旧宅, 原址 & relics \\
\hline $\mathrm{d} x^{-1}$ & $\mathrm{~V}$ & & 发芽（树木） & to sprout \\
\hline $\operatorname{di\rceil }$ & $\mathrm{CONJ}$ & & 那么，则 & else \\
\hline dur & $\mathrm{N}$ & & 泡沫 & foam \\
\hline dut & $\mathrm{N}$ & & 一 & one \\
\hline do $\rfloor$ & $\mathrm{V}$ & & 看见 & to see; to come across someone \\
\hline$d v\rfloor\rfloor$ & $\mathrm{N}$ & & 肚子 & belly, abdomen \\
\hline $\mathrm{dy}\rfloor$ & $\mathrm{N}$ & & 地 (天地的地) & earth (as in: the sky and the earth) \\
\hline dzæ」 & ADJ & & 有时间的 & free \\
\hline dze- & $\mathrm{N}$ & & 小麦 & wheat \\
\hline $\mathrm{dzY}\rfloor$ & $\mathrm{N}$ & & 冰 & ice \\
\hline $\mathrm{dz}\rceil^{-1}$ & $\mathrm{CL}$ & & 双 & a pair \\
\hline $\mathrm{dz} \mathfrak{1}\rfloor$ & $\mathrm{V}$ & & 抢 & to rob \\
\hline dzar-17i- & $\mathrm{N}$ & & 鸟名 & bird sp. \\
\hline dzr & $\mathrm{V}$ & & 拿，捉（捉鸟） & to clutch, to grasp, to catch \\
\hline dzuut & $\mathrm{N}$ & & 集市，街 ～～～～～～～待 & market, fair \\
\hline dzurJdzurt & ADJ & & 萎靡的 & listless \\
\hline dzut & $\mathrm{N}$ & & 债，债务 & debt, loan \\
\hline dzut & $\mathrm{V}$ & & 增多, 增值 & to add \\
\hline dził & $\mathrm{N}$ & & 人, 人类 & human being \\
\hline 27 & $\mathrm{~N}$ & & 二 & two \\
\hline ว७- & PREF & & 亲属称谓前缀 & $\begin{array}{l}\text { prefix used in kinship terms } \\
\text { referring to elders }\end{array}$ \\
\hline $\mathrm{e}\rfloor \mathrm{p}^{\mathrm{h}} \underline{1}-1$ & $\mathrm{~N}$ & & 嗳气 & ructus \\
\hline $\mathrm{fa}-17$ & $\mathrm{~V}$ & $\mathrm{CH}$ & 罚 & to punish \\
\hline fæ- & $\mathrm{V}$ & & 去 & to go \\
\hline fe」 & $\mathrm{N}$ & & 坟 & tomb \\
\hline 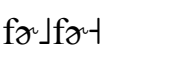 & ONO & & 风吹的声音 & hissing (wind noise) \\
\hline$f \gamma-1$ & $\mathrm{~N}$ & $\mathrm{CH}$ & 风 & wind \\
\hline fun Jfu- & ADJ & & 微风轻拂的感觉 & $\begin{array}{l}\text { gently flicking in the breeze } \\
\text { (sensation of wind) }\end{array}$ \\
\hline fo $\lrcorner \mathrm{ca}\rceil$ & $\mathrm{N}$ & $\mathrm{CH}$ & 佛教 & Buddhism \\
\hline fụ 7 & $\mathrm{~N}$ & & 老鼠 & rat \\
\hline$\gamma\rfloor$ & $\mathrm{V}$ & & 捞上来 & scoop up out of water \\
\hline$g \gamma\rfloor$ & ADJ & & 满足, 满意, 知足 & satisfied, happy \\
\hline
\end{tabular}




\begin{tabular}{|c|c|c|c|c|}
\hline gut & V & & 下（雨，雪） & to fall (snow), to snow \\
\hline gut & $\mathrm{V}$ & & 熟悉 & be familiar with \\
\hline gu」 & $\mathrm{V}$ & & 弄弯 & to bend (an object) \\
\hline hat & $\mathrm{N}$ & & 饭 & food \\
\hline hæ- & $\mathrm{V}$ & & 风 & wind \\
\hline het & $\mathrm{N}$ & & 耳朵 & ear \\
\hline $\mathrm{h} \gamma \mathrm{T}$ & ADJ & & 鼻子酸痛 & painful (nose) \\
\hline hut & $\mathrm{N}$ & & 牙齿 & tooth \\
\hline hurtlurt & ADJ & & 剔得干干净净的 & neat and tidy (eg face after shaving) \\
\hline hot & $\mathrm{N}$ & & 汤 ～～～ & soup \\
\hline hwa 7 & $\mathrm{~N}$ & & 牧人在山上暂住的木头小房 & cabin, hut \\
\hline hwæ- & ADJ & $\mathrm{CH}$ & 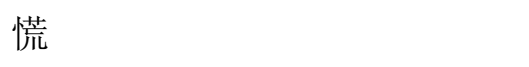 & hurried \\
\hline hwa-17zwa- & $\mathrm{N}$ & & 松鼠 & squirrel \\
\hline hwe」 & $\mathrm{V}$ & & 摔倒 & to wrestle \\
\hline hwr-17tsrt & CONJ & $\mathrm{CH}$ & 或者 & or \\
\hline hY」 & ADJ & & 红的 & red \\
\hline ho-jurt? & $\mathrm{N}$ & $\mathrm{CH}$ & 火药 & gunpowder \\
\hline i」 & ADJ & & 右 & right \\
\hline jæłæ」 & $\mathrm{N}$ & & 植物油 & vegetable oil \\
\hline jałko」 & $\mathrm{N}$ & & 家, 家里 & home, central room in the house \\
\hline je 1 & CONJ & & 所以 & so \\
\hline j $\gamma 7$ & $\mathrm{~V}$ & & 给, 送 & to give \\
\hline jwæ」 & $\mathrm{N}$ & $\mathrm{CH}$ & 圆 & circle \\
\hline jwe-17 & $\mathrm{N}$ & $\mathrm{CH}$ & 月 & moon; month \\
\hline jæ-tkæ- & $\mathrm{N}$ & & 天井 & courtyard \\
\hline fa $\left.\lrcorner_{l a}\right\lrcorner_{f} a-1 a-$ & ADJ & & 摆动之状 & swaying \\
\hline ye-17 & CLF & & 户 & (one) family \\
\hline frtdu」 & $\mathrm{N}$ & & 墙壁 & wall \\
\hline $\mathrm{ji}\lrcorner$ & $\mathrm{N}$ & & 水 & water \\
\hline jYt & $\mathrm{V}$ & & 有，存在（无生命） & existential verb \\
\hline $\mathrm{ka}\rceil$ & $\mathrm{V}$ & & 掩盖；掩埋 & to cover, to bury \\
\hline kæ」 & $\mathrm{V}$ & & 挠痒 & to itch \\
\hline ke-t & $\mathrm{V}$ & $\mathrm{CH}$ & 跟 & to follow \\
\hline 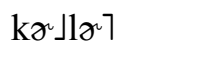 & ADJ & & 发痒的 & itchy \\
\hline $\mathrm{k} \gamma\rfloor$ & $\mathrm{V}$ & & 笁，篮选 & to sift \\
\hline kitliłkołloł & ONO & & $\begin{array}{l}\text { 吹里呱啦（翻找东西，小孩捣 } \\
\text { 蛋） }\end{array}$ & sound of rummaging through objects \\
\hline kut & ADJ & & 聪明 & wise \\
\hline kurtlunt & ADJ & & 伤心的 & sad, grieved \\
\hline ko」 & $\mathrm{N}$ & & 针 & needle \\
\hline $\mathrm{ku}\rfloor$ & $\mathrm{N}$ & & 姜 & ginger \\
\hline
\end{tabular}




\begin{tabular}{|c|c|c|c|c|}
\hline $\mathrm{kv}\urcorner$ & $\mathrm{V}$ & & 会, 能 & to be able to \\
\hline kwat & $\mathrm{V}$ & & 欺骗 & to deceive, to tell lies \\
\hline kwæ- & $\mathrm{N}$ & $\mathrm{CH}$ & 拐 & crutch \\
\hline kwe-le-t & ADJ & & 很有韧性 & supple \\
\hline kwr 7 & CLF & & 根（烟） & clf.cigarettes \\
\hline $\left.\mathrm{k}^{\mathrm{h}} \mathrm{a}\right\rceil$ & $\mathrm{V}$ & & 开 (眼睛) & to open (one's eyes) \\
\hline $\mathrm{k}^{\mathrm{h}} \mathfrak{\rceil}$ & $\mathrm{V}$ & & 射（弓箭） & to shoot (with a gun) \\
\hline $\mathrm{k}^{\mathrm{h}} \mathrm{e}-1$ & $\mathrm{~V}$ & $\mathrm{CH}$ & 肯 & to agree \\
\hline $\mathrm{k}^{\mathrm{h}} \gamma 7$ & $\mathrm{~N}$ & & 背管 & basket carried on the back \\
\hline $\mathrm{k}^{\mathrm{h}} \mathrm{i}-1 \mathrm{i}-\mathrm{k}^{\mathrm{h}} \gamma-1 \mathrm{l}$ & PN & & & sound of hurried knocking/scurrying \\
\hline ot & ONO & & 敲击声 & about \\
\hline$\left.k^{h} u\right\rceil$ & $\mathrm{V}$ & & 生（火） & to put on fire \\
\hline$k^{h} u-1$ & $\mathrm{~N}$ & & 脚 & leg \\
\hline $\mathrm{k}^{\mathrm{h}} \mathrm{ur}-1 \mathrm{urt}$ & $\mathrm{N}$ & & 洞, 孔 & aperture \\
\hline $\mathrm{k}^{\mathrm{h}} \mathrm{O} \mathrm{l}$ & $\mathrm{V}$ & & 杀, 宰 & to kill; to slaughter (an animal) \\
\hline $\mathrm{k}^{\mathrm{h}} \mathrm{u}-1$ & $\mathrm{~N}$ & & 门 & door \\
\hline $\left.\mathrm{k}^{\mathrm{h}} \mathrm{v}\right\urcorner$ & $\mathrm{N}$ & & 年 & year; year of age; age \\
\hline $\mathrm{k}^{\mathrm{h}} \mathrm{wat}$ & ADJ & & 有益, 有疗效 & effective \\
\hline $\mathrm{k}^{\mathrm{h}} \mathrm{w} \mathfrak{-}$ & ADJ & $\mathrm{CH}$ & 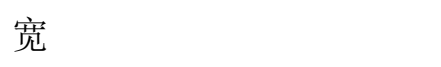 & broad \\
\hline $\mathrm{k}^{\mathrm{h}}$ wet & ADJ & $\mathrm{CH}$ & 亏 & unjust \\
\hline $\mathrm{k}^{\mathrm{h}} \mathrm{w} \gamma 7$ & $\mathrm{~N}$ & & 口子，入口 & opening; tear \\
\hline $\mathrm{la}\rceil$ & ADJ & & 厚 & thick \\
\hline læ- & $\mathrm{N}$ & & 男性生殖器 & male genitals \\
\hline 127 & $\mathrm{~V}$ & & 量 & to measure \\
\hline let & $\mathrm{N}$ & & 裤子 & trousers, pants \\
\hline $1 \gamma\rfloor$ & $\mathrm{N}$ & $\mathrm{CH}$ & 龙 & dragon \\
\hline li 7 & $\mathrm{~V}$ & & 烧（只烧掉部分） & to burn (on the surface) \\
\hline lja-17 & ONO & & 耕牛时对牛说, 让牛停下 & $\begin{array}{l}\text { shout to make cattle stop, when } \\
\text { ploughing }\end{array}$ \\
\hline ljæ- & $\mathrm{N}$ & $\mathrm{CH}$ & 两 & an ounce \\
\hline $\operatorname{lj} \gamma\rfloor$ & ADJ & & 美, 好看, 美丽 & beautiful \\
\hline lurt & $\mathrm{V}$ & & 渴求，渴望 & to anticipate \\
\hline $\operatorname{lul} 7$ & $\mathrm{~V}$ & & 小便，拉（屎） & to urinate \\
\hline lot & $\mathrm{N}$ & & 活; 工作 & work, job \\
\hline $\operatorname{lu}\rfloor$ & $\mathrm{V}$ & & 奔, 奔跑 & to gallop \\
\hline $\operatorname{lụ}^{0}$ & $\mathrm{~N}$ & & 蛆 & maggot \\
\hline lwæ7 & $\mathrm{N}$ & $\mathrm{CH}$ & 乱 & disorder \\
\hline lwrlmet & $\mathrm{N}$ & & 四月 & April \\
\hline lyt & $\mathrm{N}$ & & 果实, 果子 & fruit \\
\hline $\mathrm{mat}$ & ADJ & & 细（粉状） & fine (powder) \\
\hline mæ- & $\mathrm{N}$ & & 尾巴 & tail \\
\hline
\end{tabular}




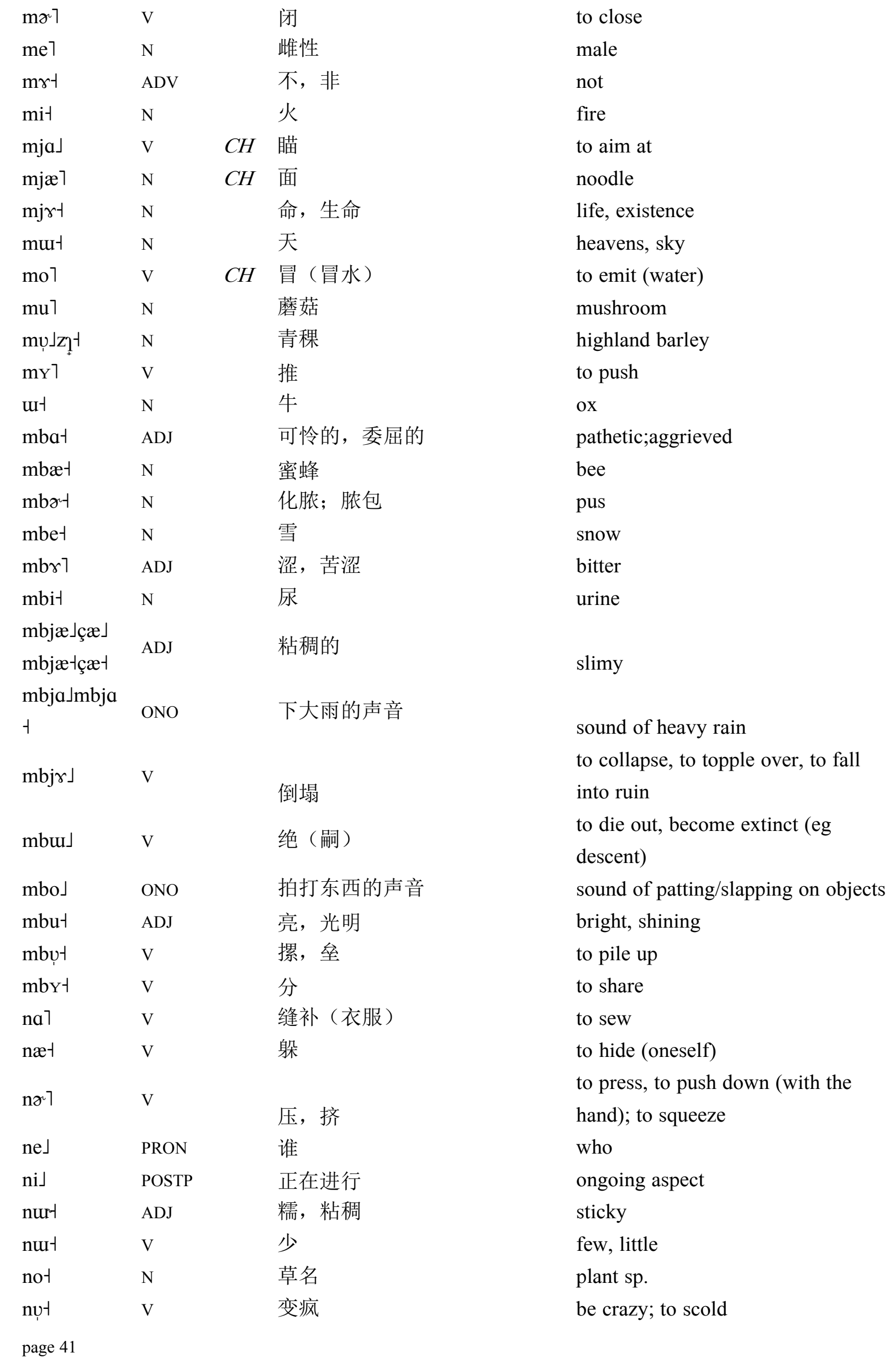




\begin{tabular}{|c|c|c|c|}
\hline nat & ADJ & 糟糕的 & too bad \\
\hline næ7 & ADJ & 淢（食物） & greasy, oily \\
\hline ne-17 & ADJ & 缓慢的 & slow \\
\hline nr 7 & ADJ & 早 & early in the morning \\
\hline nit & $\mathrm{N}$ & 鱼 & fish \\
\hline ny 7 & PRON & 自己 & oneself \\
\hline nda 7 & $\mathrm{~V}$ & 砍 & to hack \\
\hline ndæ- & $\mathrm{N}$ & 狐狸 & fox \\
\hline ndot & ADJ & 短, 短的 & short \\
\hline nde $\rfloor$ & $\mathrm{V}$ & 交媾 & to copulate \\
\hline ndi」lit & $\mathrm{V}$ & 卷 & to roll up \\
\hline ndjrt & $\mathrm{V}$ & 滴 （水往下滴） & to drip, to dribble \\
\hline ndurt & $\mathrm{V}$ & 蛰 & to sting (bee) \\
\hline ndw」 & $\mathrm{V}$ & 沉 & to sink \\
\hline ndot & $\mathrm{V}$ & 爬（山） & to climb \\
\hline $\mathrm{ndu}\rfloor$ & CLF & 坨；团 & a large chunk of \\
\hline ndụt & $\mathrm{V}$ & 刻 & to carve, to engrave \\
\hline $\begin{array}{l}\text { ndwæ Jndw } \\
æ-1\end{array}$ & ADJ & 刺痛的（腿脚） & irritated, itchy (hands or feet) \\
\hline$n d y-1$ & ADJ & 平地 & plain \\
\hline ndzat & ADJ & 瘦（人瘦） & skinny, thin (person) \\
\hline ndzæ- & $\mathrm{V}$ & 骑, 跨 & to ride (a horse) \\
\hline ndze $」$ & ADJ & 密封的, 吻合的 & hermetically (sealed) \\
\hline ndzot & $\mathrm{N}$ & 冰雼 & hail \\
\hline ndzy- & $\mathrm{V}$ & 弹飞 & to fly (of bullet, bomb) \\
\hline ndz1̣1 & $\mathrm{V}$ & 挖, 锄 & to dig \\
\hline $\mathrm{ndz} 1{ }^{1}$ & $\mathrm{~V}$ & 借 & to borrow \\
\hline ndzort & $\mathrm{V}$ & 啰嗦 & $\begin{array}{l}\text { to rant away, to speak in a wordy } \\
\text { way }\end{array}$ \\
\hline ndzurt & $\mathrm{V}$ & 游泳 & to swim, to float \\
\hline ndzut & $\mathrm{N}$ & 豹子 & leopard, panther \\
\hline ¡dzu」 & $\mathrm{V}$ & 掉落, 脱落 & to drop, to fall \\
\hline ndzut & $\mathrm{N}$ & 朋友 & friend \\
\hline ndzwat & $\mathrm{N}$ & 十字镐 & pickax \\
\hline ndzwe 1 & $\mathrm{~V}$ & 串珠 & to string (beads); to put on (a skirt) \\
\hline ndzi $\rceil$ & ONO & 清脆的铃铛声 & clear and sharp sound of bell \\
\hline nfar 7 & $\mathrm{~V}$ & 烤，多 & to roast, to grill \\
\hline nfr」 & ADJ & 艰苦的, 贫困的 & arduous \\
\hline nfit & $\mathrm{N}$ & 酒曲 & yeast \\
\hline nfY- & ADJ & 硬的, 僵硬的 & hard, solid, resilient \\
\hline ya」 & PRON & 我 & $1 \mathrm{sg}$ \\
\hline
\end{tabular}




\begin{tabular}{|c|c|c|c|c|}
\hline yæ」 & $\mathrm{V}$ & $\mathrm{CH}$ & 挨, 忍 & to bear, to tolerate \\
\hline ge 7 & ADJ & $\mathrm{CH}$ & 硬 & hard, solid, resilient \\
\hline y & PRON & & 我 & $1 \mathrm{sg}$ \\
\hline yụ & $\mathrm{N}$ & & 银子 & silver \\
\hline ygat & $\mathrm{V}$ & & 胜利 & to win, to succeed \\
\hline ygæ- & $\mathrm{V}$ & & 占, 霸占 & to predominate \\
\hline ygr」 & $\mathrm{V}$ & & 灭，熄 & to go out (fire) \\
\hline $\begin{array}{l}\text { ygi-liłngo- } \\
\text { lo-1 }\end{array}$ & ONO & & 打雷声 & sound of thunderclap \\
\hline ygu-1 & $\mathrm{V}$ & & 嚼 & to chew; to chew the cud \\
\hline ygo $」$ & $\mathrm{~N}$ & & 臼齿 & molars \\
\hline ggu」 & $\mathrm{V}$ & & 生病；痛 & sick; pain \\
\hline ygụt & $\mathrm{V}$ & & 打雷 & to thunder \\
\hline ygwæ- & ONO & & 咣 & banging sound \\
\hline ggwrt & $\mathrm{V}$ & & 㻌, 欠 & to buy on credit \\
\hline 07 & $\mathrm{~V}$ & & 倒，倾倒 & to pour out \\
\hline pat & $\mathrm{N}$ & & 青蛙 & frog \\
\hline pæ」 & $\mathrm{V}$ & & 拉开, 劝架 & to exhort; to urge; to persuade \\
\hline pr 7 & $\mathrm{~V}$ & & 梳 & to comb \\
\hline pe 1 & $\mathrm{~N}$ & & 糟粕 & dregs, residue \\
\hline pr」 & $\mathrm{N}$ & & 穗 & ear (of grain) \\
\hline pił & $\mathrm{V}$ & & (被水) 漂走, 冲走 & $\begin{array}{l}\text { to drift away (on water), to be } \\
\text { washed away (by water) }\end{array}$ \\
\hline pja-t & $\mathrm{N}$ & $\mathrm{CH}$ & 表 & watch \\
\hline pjæ 1 & $\mathrm{~V}$ & $\mathrm{CH}$ & 变 & to change (to undergo change) \\
\hline pjrt & $\mathrm{V}$ & & 搬动 & to move \\
\hline put & $\mathrm{N}$ & & 艾蒿 & Chinese mugwort, artemisia \\
\hline pur?lunt & $\mathrm{N}$ & & 胸脯 & chest \\
\hline pot & $\mathrm{N}$ & $\mathrm{CH}$ & 宝 & treasure \\
\hline put & $\mathrm{V}$ & & 叮, 衔 & hold in the mouth \\
\hline pụ & $\mathrm{N}$ & & 蒸笼 & food steamer \\
\hline py 7 & $\mathrm{~N}$ & & 蚂蟥 & leech \\
\hline$p^{h} a-1$ & $\mathrm{~N}$ & & 脸 & face \\
\hline $\mathrm{p}^{\mathrm{h}} \mathfrak{t}-1$ & $\mathrm{~V}$ & & 拴（牛） & to tie, to fasten (an animal) \\
\hline $\mathrm{p}^{\mathrm{h}} \mathrm{\partial}^{\mathrm{J}}$ & ADJ & & 白 & white \\
\hline$p^{h}$ e-t & $\mathrm{V}$ & & 簛 & to winnow with a fan \\
\hline $\mathrm{p}^{\mathrm{h}} \gamma-17$ & $\mathrm{~V}$ & $\mathrm{CH}$ & 拍 & to clap, to knock \\
\hline $\left.\mathrm{p}^{\mathrm{h}} \mathrm{i}\right\rceil$ & $\mathrm{V}$ & & 丢, 丢弃 & to abandon, to give up \\
\hline $\mathrm{p}^{\mathrm{h}_{\mathrm{ja}}-1}$ & $\mathrm{~V}$ & $\mathrm{CH}$ & 飘 & to drift about \\
\hline $\mathrm{p}^{\mathrm{h}} \mathrm{j} æ 7$ & $\mathrm{~V}$ & $\mathrm{CH}$ & 骗 & to deceive \\
\hline $\mathrm{p}^{\mathrm{h}} \mathrm{je}-17$ & $\mathrm{~V}$ & $\mathrm{CH}$ & 粘 & to cast aside \\
\hline
\end{tabular}




\begin{tabular}{|c|c|c|c|c|}
\hline $\mathrm{p}^{\mathrm{h}} \mathrm{j} \gamma \mathrm{T}$ & $\mathrm{N}$ & & 叶子 & leaf \\
\hline$p^{h} u-1$ & $\mathrm{~V}$ & & 糠 & chaff \\
\hline $\mathrm{p}^{\mathrm{h}} \mathrm{o}$ & $\mathrm{N}$ & $\mathrm{CH}$ & 炮 & cannon \\
\hline $\mathrm{p}^{\mathrm{h}} \mathrm{u}-\mathrm{t}$ & $\mathrm{V}$ & & 打开 & to open (e.g. a door) \\
\hline $\mathrm{p}^{\mathrm{h}} \underline{v}-1$ & $\mathrm{~N}$ & & 雄性 & male \\
\hline $\left.\mathrm{p}^{\mathrm{h}} \mathrm{Y}\right\rceil$ & $\mathrm{V}$ & & 呕吐 & to vomit \\
\hline sat & $\mathrm{N}$ & & 亚麻 & hemp \\
\hline sæ- & $\mathrm{N}$ & & 血 & blood \\
\hline set & $\mathrm{N}$ & & 癣 & tinea, ringworm \\
\hline sit & ADJ & & 穷, 贫穷 & poor (person) \\
\hline sjæłi- & ADJ & $\mathrm{CH}$ & 便宜 & cheap \\
\hline sje-17 & ADJ & $\mathrm{CH}$ & 斜 & slanting \\
\hline sot & $\mathrm{V}$ & & 尝, 品尝 & to taste \\
\hline swæ $\rfloor_{\text {swæ- }}$ & ONO & & 下雨声 & sound of rain \\
\hline swe-t & $\mathrm{N}$ & & 官 & official \\
\hline sy- & $\mathrm{V}$ & & 打掉（油花）, 修剪（头发） & to skim (foam) \\
\hline s? 7 & $\mathrm{~V}$ & & 捡，拾 & to pick up \\
\hline sq̣-1 & $\mathrm{V}$ & & 喜欢, 上瘾 & to like \\
\hline sat & $\mathrm{N}$ & $\mathrm{CH}$ & 沙 & sand \\
\hline$s \gamma 7$ & $\mathrm{~N}$ & & 污垢, 汗渍 & dirt, filth \\
\hline set & CLF & $\mathrm{CH}$ & 升 & clf.liters \\
\hline$s \gamma-1$ & ADJ & & 严重的; 耗费的 & severe \\
\hline şurt & ADJ & & 明显的 & obvious \\
\hline șüt & $\mathrm{N}$ & & 肉 & meat \\
\hline sut & $\mathrm{N}$ & & 䖝子 & louse \\
\hline sut & $\mathrm{V}$ & & 产崽（动物） & to birth (animal) \\
\hline șa」 & ADJ & & 高, 高的 & high \\
\hline șwæ $\rceil$ & $\mathrm{V}$ & $\mathrm{CH}$ & 涮 & to rinse \\
\hline swet & $\mathrm{V}$ & & 干, 做; 放 & to do, to put into \\
\hline tat & $\mathrm{V}$ & & 卡住 & $\begin{array}{l}\text { to clutch, to catch hold of, to hold } \\
\text { on a hook }\end{array}$ \\
\hline tæ1 & $\mathrm{V}$ & & 结 (果) & to yield fruit \\
\hline to 7 & $\mathrm{~V}$ & & 关 (门, 羊) & $\begin{array}{l}\text { to lock up (animals), to close (a } \\
\text { door) }\end{array}$ \\
\hline te 7 & $\mathrm{~V}$ & & 吃，喝 & to eat \\
\hline ti-tił & $\mathrm{V}$ & & 触碰 & to touch upon, to bump into \\
\hline $\mathrm{tja}\rceil$ & $\mathrm{V}$ & $\mathrm{CH}$ & 吊 & to hang up \\
\hline tjæ7 & $\mathrm{N}$ & $\mathrm{CH}$ & 电 & electricity \\
\hline tjrt & $\mathrm{V}$ & & 受罪 & to endure hardship/torture \\
\hline tjr-17 & $\mathrm{V}$ & $\mathrm{CH}$ & 叠 & to fold (clothes) \\
\hline $\operatorname{tur} 7$ & $\mathrm{~V}$ & & 纺, 织 & to weave \\
\hline
\end{tabular}




\begin{tabular}{|c|c|c|c|c|}
\hline twot & $\mathrm{V}$ & & 起（床） & to get up \\
\hline tot & $\mathrm{V}$ & & 依靠，枕 & to lean on, to rest against sth \\
\hline tuJtut & ONO & & 火很旺的声音 & sound of intense fire \\
\hline tw」 & $\mathrm{N}$ & & 千 & 1,000 \\
\hline ty-1 & $\mathrm{V}$ & & 打 & $\begin{array}{l}\text { to beat (e.g. with the head of a } \\
\text { hammer) }\end{array}$ \\
\hline twæJtwæ- & ONO & & 敲击声 & sound of knocking \\
\hline $\left.\mathrm{t}^{\mathrm{h}} \mathrm{a}\right\rceil$ & $\mathrm{V}$ & & 可以 & may \\
\hline $\mathrm{t}^{\mathrm{h}} \mathfrak{- 1}$ & $\mathrm{V}$ & & 戴 & to wear (a hat) \\
\hline $\mathrm{t}^{\mathrm{h}} \mathrm{x}^{\mathrm{\gamma}}$ & $\mathrm{V}$ & & 咬, 叮 & to bite; to sting, to gnaw, to nibble \\
\hline$t^{\mathrm{h}} \mathrm{e}-\mathrm{ur}$ & $\mathrm{N}$ & & 书 & book \\
\hline $\left.\mathrm{t}^{\mathrm{h}} \mathrm{i}\right\rfloor$ & $\mathrm{N}$ & & 刨 & plane \\
\hline $\left.\mathrm{t}^{\mathrm{h}} \mathrm{ja}\right\rceil$ & $\mathrm{V}$ & $\mathrm{CH}$ & 跳 & to jump \\
\hline $\mathrm{t}^{\mathrm{h}} \mathrm{j} \mathfrak{-}$ & $\mathrm{N}$ & $\mathrm{CH}$ & 天 & heavens, sky \\
\hline $\left.\left.\mathrm{t}^{\mathrm{h}} \mathrm{je}\right\lrcorner \mathrm{kwæ}\right\rceil$ & $\mathrm{N}$ & $\mathrm{CH}$ & 铁矿 & iron ore \\
\hline $\left.\mathrm{t}^{\mathrm{h}} \mathrm{j} \gamma\right\rceil$ & CLF & & 滴 & drop \\
\hline$t^{\mathrm{h}} u-1$ & PRON & & 他, 它, 她 & $3 \mathrm{sg}$ \\
\hline$t^{\mathrm{h}} \mathrm{ur} 7 \mathrm{lur}$ & $\mathrm{V}$ & & 包裹 & to pack \\
\hline $\mathrm{t}^{\mathrm{h}} \mathrm{o}-1$ & $\mathrm{~N}$ & & 松 & pine \\
\hline$t^{\mathrm{h}} \underline{v}-1$ & $\mathrm{~V}$ & & 起（泡，疮㾑，毛球） & to have (a bladder) \\
\hline$t^{\mathrm{h}} w æ-1$ & $\mathrm{~V}$ & & 敲（额头） & to knock (one's forehead) \\
\hline $\left.\mathrm{t}^{\mathrm{h}} \mathrm{Y}\right\rfloor \mathrm{l} \mathrm{Y}$ & $\mathrm{N}$ & & 大箕箕 & large winnowing fan \\
\hline tca $\rceil$ & ONO & & 驾（赶马的叫声） & cry to urge a horse forward \\
\hline tert & $\mathrm{N}$ & $\mathrm{CH}$ & 酒 & wine, spirits \\
\hline tci & $\mathrm{V}$ & & 追 & to chase after; to pursue \\
\hline tçæ-cwe-t & $\mathrm{N}$ & $\mathrm{CH}$ & 将军 & general \\
\hline $\left.\operatorname{tc} \varphi^{\mathrm{h}} \mathrm{i}\right\rfloor$ & $\mathrm{V}$ & & 来 & to come \\
\hline$\left.t \varphi^{\mathrm{h}} \mathrm{a}\right\rceil$ & V & $\mathrm{CH}$ & 輫 & to pry open \\
\hline$t \varphi^{\mathrm{h}} æ-1$ & $\mathrm{~N}$ & $\mathrm{CH}$ & 枪 & gun \\
\hline$t 6^{\mathrm{h}} \gamma-1$ & $\mathrm{~N}$ & $\mathrm{CH}$ & 秋 & autumn \\
\hline tsat & $\mathrm{V}$ & & 背负 & to carry on one's back; to shoulder \\
\hline tsæ- & $\mathrm{V}$ & & 移动 & to move \\
\hline tse-t & $\mathrm{V}$ & & 剁 & to chop \\
\hline $\mathrm{ts}^{\mathrm{h}} \mathrm{O}-\mathrm{t}$ & $\mathrm{N}$ & & 楼 & two-story building \\
\hline $\left.\operatorname{ts}^{\mathrm{h}} \mathrm{Y}\right\rceil$ & $\mathrm{V}$ & & 赔偿 & to compensate for, to pay back \\
\hline tso $\rfloor$ & $\mathrm{V}$ & & 装好（用口袋） & to pack properly (in a bag) \\
\hline tswæ 1 & $\mathrm{~V}$ & $\mathrm{CH}$ & 钻 & to drill \\
\hline tswe 7 & ADV & $\mathrm{CH}$ & 最 & most \\
\hline tsy 7 & $\mathrm{~V}$ & & 留给 & to reserve for \\
\hline tsộ-1 & $\mathrm{V}$ & & 拴, 绑, 捆 & to tie \\
\hline tsp̣ 7 & $\mathrm{~V}$ & & 据说 & reported-speech part. \\
\hline
\end{tabular}




\begin{tabular}{|c|c|c|c|c|}
\hline $\left.\operatorname{ts}^{\mathrm{h}} \mathrm{a}\right\rceil$ & V & & 咬，咬合 & to bite \\
\hline $\mathrm{ts}^{\mathrm{h}} \mathfrak{x}-1$ & $\mathrm{~N}$ & & 寄生植物名 & parasitic plant sp. \\
\hline $\left.\left.\mathrm{ts}^{\mathrm{h}}\right\rceil_{1}\right\rceil$ & $\mathrm{V}$ & & 建（房子） & to build \\
\hline $\mathrm{ts}^{\mathrm{h}} \underline{1}^{-1}$ & ADJ & & 热 & hot \\
\hline$t^{\mathrm{h}} \mathrm{e}-\mathrm{t}$ & $\mathrm{N}$ & & 盐 & salt \\
\hline $\left.\mathrm{ts}^{\mathrm{h}} \mathrm{w}\right\rfloor$ & ONO & & 油炸的声音 & sizzling (of boiling oil) \\
\hline $\operatorname{ts} 27$ & $\mathrm{~V}$ & & 淹，淹没 & to submerge \\
\hline tset & $\mathrm{V}$ & $\mathrm{CH}$ & 蒸 & to steam (food) \\
\hline $\operatorname{ts} \gamma\rfloor$ & $\mathrm{N}$ & & 爪，爪子 & claw \\
\hline tsurt & $\mathrm{V}$ & & 咳嗽 & to cough \\
\hline tsurt & $\mathrm{N}$ & & 土 & earth \\
\hline tsut & $\mathrm{V}$ & & 射中; 扎, 刺入 & to score a hit \\
\hline tSụt & $\mathrm{V}$ & & 接，迎接 & $\begin{array}{l}\text { to receive, to meet, to welcome } \\
\text { (someone) }\end{array}$ \\
\hline tșwat & $\mathrm{N}$ & & 床 & bed \\
\hline tswæ- & $\mathrm{N}$ & $\mathrm{CH}$ & 砖 & brick \\
\hline tswe 7 & $\mathrm{~V}$ & $\mathrm{CH}$ & 坠 & to fall,to drop \\
\hline $\operatorname{tsch}^{\mathrm{h}} \gamma \mathrm{u}$ & $\mathrm{V}$ & & 指使 & to instigate \\
\hline $\left.\mathrm{ts}^{\mathrm{h}} \mathrm{e}\right\rfloor$ & $\mathrm{N}$ & $\mathrm{CH}$ & 城 & city \\
\hline $\operatorname{tss}^{\mathrm{h}_{\gamma-1}}$ & $\mathrm{~N}$ & $\mathrm{CH}$ & 车 & car \\
\hline$t^{\mathrm{h}}{ }^{\mathrm{h}} \mathrm{ur}-\mathrm{t}$ & $\mathrm{V}$ & & 兑，掺 & to add water, to pour extra water \\
\hline ts $s^{\mathrm{h}} \mathrm{u}-1$ & $\mathrm{~V}$ & & 悬挂, 挂在墙上 & to suspend, to hang (in a place) \\
\hline $\left.\mathrm{ts}^{\mathrm{h}} \mathrm{o}-1 \mathrm{o}\right\rfloor$ & PRON & & 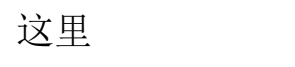 & here \\
\hline$t^{\mathrm{s}}{ }^{\mathrm{h}} \mathrm{u}-$ & $\mathrm{V}$ & & 读 & to read \\
\hline $\operatorname{tss}^{\mathrm{h}} v-1$ & $\mathrm{~V}$ & & 打洞, 打孔 & to lance, to puncture \\
\hline $\left.\mathrm{ts}^{\mathrm{h}} \mathrm{wa}\right\rceil$ & $\mathrm{N}$ & & 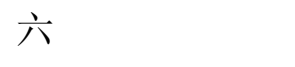 & $\operatorname{six}$ \\
\hline$t^{\mathrm{h}} \mathrm{w} æ-1$ & $\mathrm{~V}$ & $\mathrm{CH}$ & 穿 & to wear \\
\hline $\left.\mathrm{ts}^{\mathrm{h}} \mathrm{we}\right\rceil$ & ADJ & $\mathrm{CH}$ & 脆 & crisp \\
\hline ts ${ }^{\mathrm{h}} \mathrm{we}-\mathrm{t}$ & $\mathrm{V}$ & $\mathrm{CH}$ & 吹 & to boast \\
\hline $\mathrm{u}-\mathrm{t}$ & $\mathrm{V}$ & & 肿 & to swell \\
\hline væ- & $\mathrm{N}$ & $\mathrm{CH}$ & 网 & net \\
\hline vet & ADJ & $\mathrm{CH}$ & 稳 & steady \\
\hline 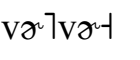 & $\mathrm{V}$ & & 拖动, 移动 & to move \\
\hline vu」vüt & ADJ & & 紧紧的 & tight \\
\hline ৩」 & $\mathrm{V}$ & & 认为 & to think \\
\hline wat & $\mathrm{N}$ & & 五 & five \\
\hline wæ- & $\mathrm{N}$ & & 左 & left \\
\hline we」 & $\mathrm{V}$ & $\mathrm{CH}$ & 围 & to enclose \\
\hline wrt & $\mathrm{V}$ & & 堆（沙） & to make a heap of (e.g. cereals) \\
\hline $\mathrm{Y}\rfloor$ & ADJ & & 轻 & light \\
\hline $\mathrm{za}-1$ & $\mathrm{~N}$ & & 鞋 & shoe \\
\hline
\end{tabular}




\begin{tabular}{|c|c|c|c|c|}
\hline $\mathrm{zæ}\rfloor$ & V & & 笑 & to mock, to laugh \\
\hline zet & $\mathrm{V}$ & & 削（果皮） & to peel (with a knife) \\
\hline $\mathrm{zi}\rfloor$ & ONO & & 锯木的声音 & sound of sawing \\
\hline zot & $\mathrm{N}$ & & 男性, 儿子 & son; man, male person \\
\hline zwæ」 & ONO & & 下雨的声音 & sound of rain \\
\hline $\mathrm{ZY}\rceil \mathrm{ZY}\rfloor$ & $\mathrm{N}$ & & 小孩儿 & child \\
\hline$z_{1}^{-1}$ & $\mathrm{~N}$ & & 命 & life \\
\hline$z_{1}^{-1}$ & $\mathrm{~V}$ & & 憋（尿）；忍耐 & to endure \\
\hline$z x^{-1}$ & ADJ & & 害怕 & scare; to be afraid \\
\hline $\mathrm{za}\rceil$ & $\mathrm{V}$ & $\mathrm{CH}$ & 绕 & to circle; to coil \\
\hline zet & $\mathrm{V}$ & $\mathrm{CH}$ & 忍 & to tolerate \\
\hline$z \gamma-1$ & $\mathrm{~V}$ & & 骟 & to wether \\
\hline zurt & $\mathrm{V}$ & & 不出声, 装作没听见 & to keep silent \\
\hline zuit & $\mathrm{N}$ & & 酒 & fermented alcohol, wine \\
\hline zut & $\mathrm{N}$ & & 午饭 & lunch \\
\hline zu」 & $\mathrm{V}$ & & 娶 & to wive \\
\hline zwat & $\mathrm{N}$ & & 马 & horse \\
\hline z̧we \jwe-t7 & $\mathrm{N}$ & $\mathrm{CH}$ & 闰月 & leap month \\
\hline
\end{tabular}

